Graphical Abstract

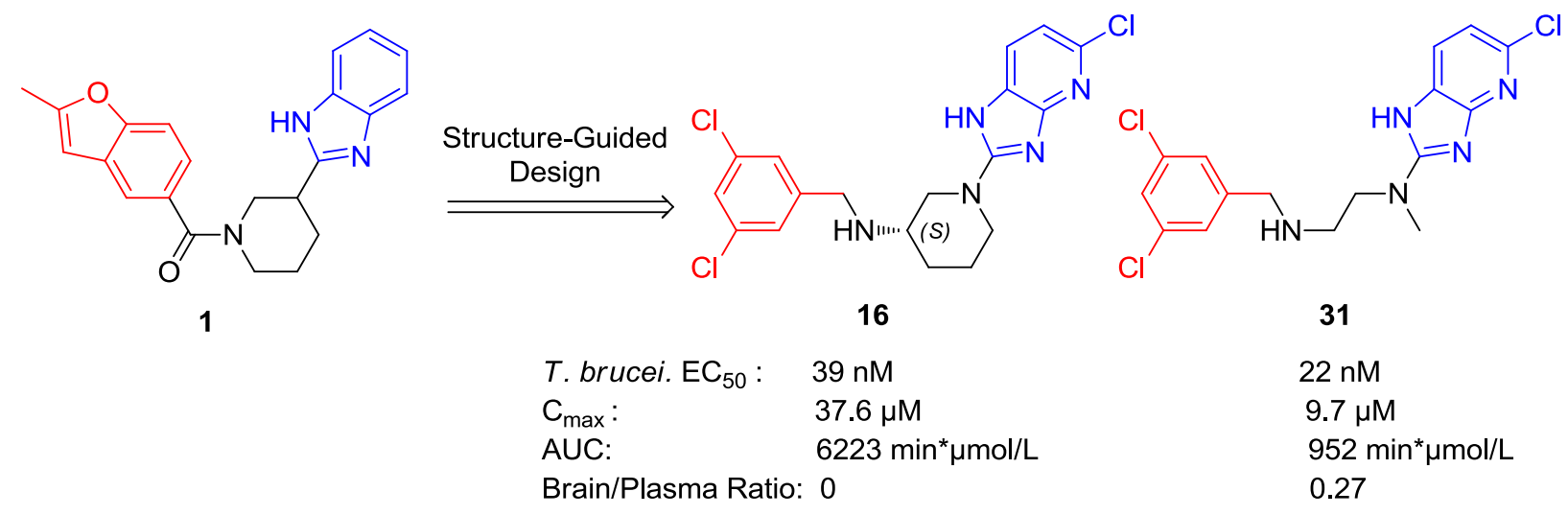

(C) 2016. This manuscript version is made available under the Elsevier user license http://www.elsevier.com/open-access/userlicense/1.0/ 


\title{
Structure-Guided Design of Novel Trypanosoma brucei Methionyl-tRNA Synthetase Inhibitors
}

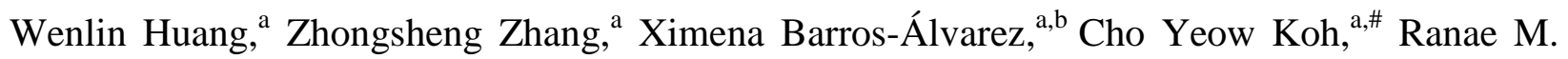
Ranade, ${ }^{c}$ J. Robert Gillespie, ${ }^{c}$ Sharon A. Creason, ${ }^{c}$ Sayaka Shibata, ${ }^{a}$ Christophe L. M. J. Verlinde, ${ }^{\mathrm{a}}$ Wim G. J. Hol, ${ }^{\mathrm{a}}$ Frederick S. Buckner, ${ }^{\mathrm{c}, *}$ Erkang Fan $^{\mathrm{a}, *}$

\begin{abstract}
A screening hit 1 against Trypanosoma brucei methionyl-tRNA synthetase was optimized using a structure-guided approach. The optimization led to the identification of two novel series of potent inhibitors, the cyclic linker and linear linker series. Compounds of both series were potent in a T. brucei growth inhibition assay while showing low toxicity to mammalian cells. The best compound of each series, 16 and 31, exhibited $\mathrm{EC}_{50} \mathrm{~s}$ of 39 and $22 \mathrm{nM}$, respectively. Compounds 16 and 31 also exhibited promising PK properties after oral dosing in mice. Moreover, compound 31 had moderately good brain permeability, with a brain/plasma ratio of 0.27 at 60 min after IP injection. This study provides new lead compounds for arriving at new treatments of human African trypanosomiasis (HAT).
\end{abstract}

\section{Key Words}

Human African trypanosomiasis, Methionyl-tRNA synthetase, Structure-guided design.

\section{INTRODUCTION}

Human African trypanosomiasis (HAT) is a parasitic disease caused by the protozoan Trypanosoma brucei [1,2]. The disease is endemic in some regions of sub-Saharan Africa, causing infection risk to 70 million people $[3,4]$. Without treatment, the disease is invariably fatal. Current treatment for HAT includes suramin, pentamidine, melarsoprol, eflornithine, or a 
combination of nifurtimox and eflornithine [2,5]. These drugs have many shortcomings, including high toxicity and/or require administration by injection [6]. Thus, there is urgent need for the development of new therapeutics that are effective, safe, easy to administer, and affordable.

Methionyl-tRNA synthetase (MetRS) of T. brucei (TbMetRS) plays an essential role in protein translation, providing the methionine charged tRNAs needed for biosynthesis of protein peptide chains [7]. It has been shown that TbMetRS is an attractive drug target for the development of a new HAT treatment [8,9]. However, some previously reported inhibitors have drawbacks. For example, the aminoquinolone-based analogues of inhibitors that target bacterial MetRS [10,11] have poor PK profiles and poor membrane permeability despite potent in vitro activity against $T$. brucei parasites [8]. Urea-based inhibitors have improved pharmacokinetic characteristics and membrane permeability, but their potency against the parasites is suboptimal [9]. As part of our continued effort to discover novel MetRS inhibitors, a high-throughput screen of the NIH Molecular Libraries Small Molecule Repository was performed with TbMetRS [12], leading to the discovery of compound $\mathbf{1}$. In this paper we report the structure-guided optimization of $\mathbf{1}$ that resulted in novel TbMetRS inhibitors with good potency, high selectivity, promising PK properties as well as brain permeability.

\section{RESULTS AND DISCUSSION}

\section{Molecular design}

Compound 1 (Figure 1E) was identified as a weak inhibitor of TbMetRS in a high-throughput orthogonal screening [12], showing $78 \%$ and $20 \%$ inhibition in a TbMetRS aminoacylation assay at 10 and $1 \mu \mathrm{M}$ respectively. Compound 1 can be chemically parsed into three parts: a benzimidazole moiety, a benzofuran moiety, and a linker connecting these two aryl rings. Similarly, compound 2 (Figure 1E), a potent TbMetRS inhibitor reported previously [12-15], also contains a benzimidazole moiety connected by a linker to an aryl ring (3,5-dichlorophenyl group). The benzimidazole moiety has already been identified as an effective fragment that binds the "auxiliary pocket" (AP) of TbMetRS [14]. The new attachment mode of the benzimidazole group to the other aryl moiety (benzofuran) seen in compound $\mathbf{1}$ provided opportunities to arrive at $T b$ MetRS inhibitors with alternative linkers. 
To aid the design of new inhibitors, a crystal structure of TbMetRS with compound 1 (Figure 1A) was obtained at $2.7 \AA$ resolution (Table S1). The binding mode of compound $\mathbf{1}$ was compared to compound $\mathbf{2}$ bound to TbMetRS and analyzed in detail (Figure 1B). The benzimidazole group of compound $\mathbf{1}$ binds similarly to the "auxiliary pocket" (AP) compared to compound 2. Both compounds interact with the AP by means of hydrophobic interactions with residues His289, Gly290 and Val473. A previously observed hydrogen bond interaction between the catalytic residue Asp287 and the benzimidazole moiety in compound 2 is also formed by compound 1 (Figure 1D). However, there is a shift of $1.2 \AA$ away from the binding pocket of the benzimidazole moiety of compound 1 with respect to 2 (Figure 1B). At the other end of compound 1, the benzofuran moiety occupies the "enlarged methionine pocket" (EMP) (Figure 1C), which is formed mainly by hydrophobic residues (including the ones engaged in methionine binding) and interacts favorably with residue Phe522. However, compared to compound 2, the benzofuran binding of compound 1 leaves a void that is filled by the 3-chlorine of the 3,5dichloro-benzene moiety in compound 2 (Figure 1C) providing in the latter case favorable hydrophobic interactions specially with residue Trp474. In the linker region, the piperidine ring in compound $\mathbf{1}$ restricts the conformational freedom of the linker. The piperidine ring is also engaged in hydrophobic interactions with residue Tyr250 (Figure 1D), adding to the previously described $T b$ MetRS•inhibitor stacking interactions [13]. 

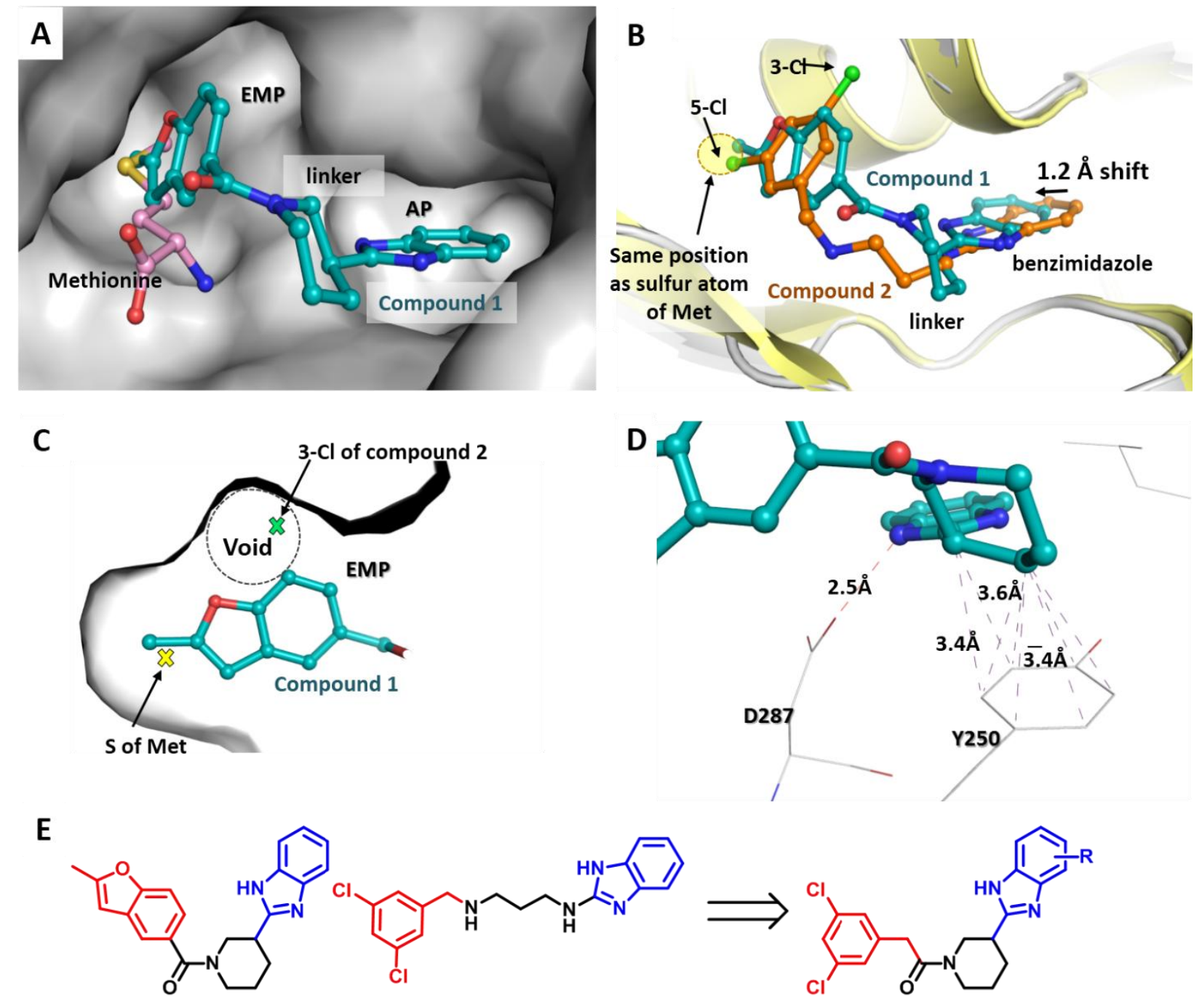

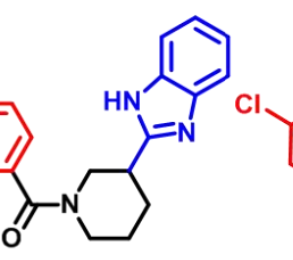

1<smiles>Clc1ccc(CNCCCNc2nc3ccccc3[nH]2)cc1</smiles>

2

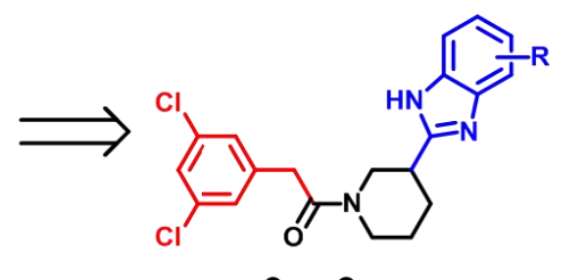

$3-8$

Figure 1. Crystal structures of compounds 1 and $\mathbf{2}$ in complex with TbMetRS and the design strategy of new compounds. (A) Compound 1 (cyan carbons) in the TbMetRS active site, bound methionine from a previously determined structure (PDB: 4EG1) is shown as a reference (pink carbons) [13]; (B) Superimposed structures of compounds $\mathbf{1}$ (cyan) and $\mathbf{2}$ (orange) in complex with TbMetRS; (C) A void existing in the EMP when the benzofuran group of compound 1 binds; (D) The piperidine ring in the linker of compound $\mathbf{1}$ interacts with Tyr250; (E) Inhibitor design strategy of combining compounds $\mathbf{1}$ and 2.

From comparing the binding modes of compounds $\mathbf{1}$ and $\mathbf{2}$, we hypothesized that hybridizing elements of both compounds would lead to a novel chemo-type exploiting the best features of both parental compounds (Figure 1E). Considering that the 3,5-dichlorophenyl moiety in compound 2 was established as a preferred fragment for the EMP $[9,14]$ and it binds more 
efficiently (no void) than the benzofuran moiety in compound 1, we decided to fix it as the fragment to fill the EMP in all the designed compounds reported here. We focused our investigation on varying the portion that occupies the AP as well as the linker. First, we made variants of the fragment occupying the AP. The shift in binding position of the benzimidazole as described in Figure 1B suggests that adding substituents to the benzene ring of the benzimidazole moiety might improve contacts with the AP. Thus, compounds 3-9 with different substitutions on the benzimidazole (or imidazopyridine) moiety (Table 1) were designed, synthesized and evaluated, which led to the discovery of 5-chloro-benzimidazole (or 5-chloroimidazopyridine) moiety as the favored fragment for binding the AP. Then, we continued our investigation of the linker part while maintaining the 3,5-dichlorophenyl and the 5-chlorobenzimidazole (or 5-chloro-imidazopyridine) moieties. A series of compounds 10-31 with varied linkers were designed, synthesized and evaluated as summarized in Table 2.

\section{Compound synthesis}

Several synthetic strategies were used to generate the target compounds. The synthetic routes used to generate inhibitors are shown in Schemes 1-5. Compounds 3-13 and 26 were prepared using the procedure shown in Scheme 1. Substituted carboxylic acids $\mathbf{3 2}$ were reacted with an appropriate aryl diamine $\mathbf{3 3}$ to generate the amide intermediates $\mathbf{3 4}$. The amide intermediates were cyclized in acetic acid to generate the target compounds.

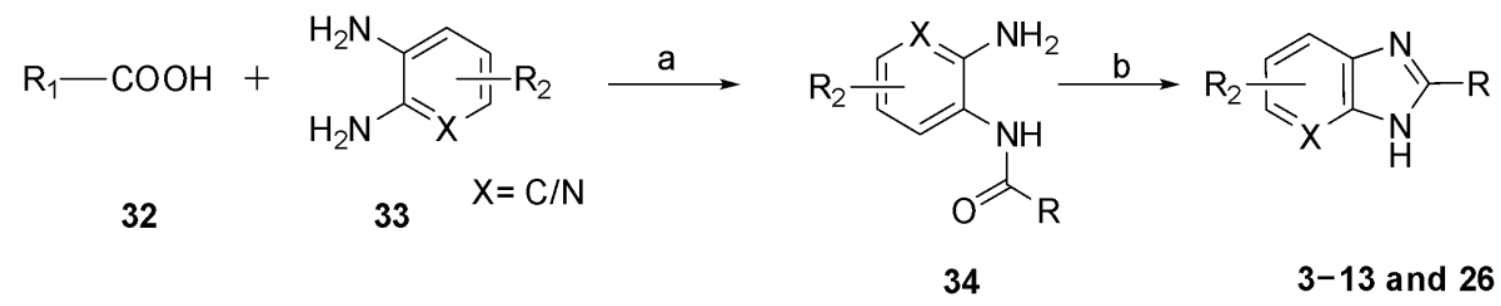

Scheme 1. Reagents and conditions: (a) EDC, pyridine, r.t. overnight; (b) $\mathrm{X}=\mathrm{C}$ : $\mathrm{AcOH}, 60{ }^{\circ} \mathrm{C}$, 3h; $\mathrm{X}=\mathrm{N}$ : AcOH, $\mathrm{POCl}_{3}$, Microwave $150{ }^{\circ} \mathrm{C}, 1 \mathrm{~h}$.

The synthetic route shown in Scheme 2 was used to synthesize compounds 14-25 and 31. Linkers were introduced by nucleophilic substitution of 2-bromo-5-chloro-1H-imidazo[4,5b]pyridine with appropriate amines, followed by Boc deprotection with TFA when necessary. Reductive amination of $\mathbf{3 7}$ with 3,5-dichlorobenzaldehyde produced the target compounds. 
(c) $36 \mathrm{X}=\mathrm{N}, \mathrm{R}=\mathrm{Boc} / \mathrm{H}$ $\mathrm{X}-\mathrm{Y}$ is linear or cyclic amine

$14-25$ and 31

Scheme 2. Reagents and conditions: (a) Pyridine, MW, $100{ }^{\circ} \mathrm{C}, 30 \mathrm{~min}$; (b) R=Boc, TFA, DCM, r.t., overnight; (c) DIPEA, $\mathrm{NaBH}_{3} \mathrm{CN}$, $\mathrm{AcOH}, \mathrm{CH}_{3} \mathrm{OH}$, r.t., overnight.

Linear linker compound 27 was synthesized following procedures shown in Scheme 3. The 1Himidazo[4,5-b]pyridine ring was generated through reacting 6-chloropyridine-2,3-diamine with the desired aldehyde. The Boc protected intermediate $\mathbf{3 8}$ was then deprotected with TFA. After Boc deprotection, reductive amination was performed to give compound 27.<smiles>CC(C)(C)[13C](=O)c1ccc(Cl)nc1NCCCCc1nc2ccc(Cl)nc2[nH]1</smiles>
33

38 27

Scheme 3. Reagents and conditions: (a) $\mathrm{NaHSO}_{3}, \mathrm{DMF}, 100{ }^{\circ} \mathrm{C}$; (b) $\mathrm{TFA}, \mathrm{CH}_{2} \mathrm{Cl}_{2}$; (c) 3,5dichloro benzaldehyde, $\mathrm{MeOH}, \mathrm{NaBH}_{3} \mathrm{CN}$.

The synthetic route shown in Scheme 4 was used to obtain linear linker compound 28. The linker was introduced by alkylating 5-chloro-1H-imidazo[4,5-b]pyridine-2(3H)-thione with 2-(2bromoethyl)isoindoline-1,3-dione. The alkylated intermediate $\mathbf{4 0}$ was then deprotected with hydrazine to produce the free amine intermediate 41. Reductive amination of $\mathbf{4 1}$ with 3,5dichlorobenzaldehyde generated compound 28. 


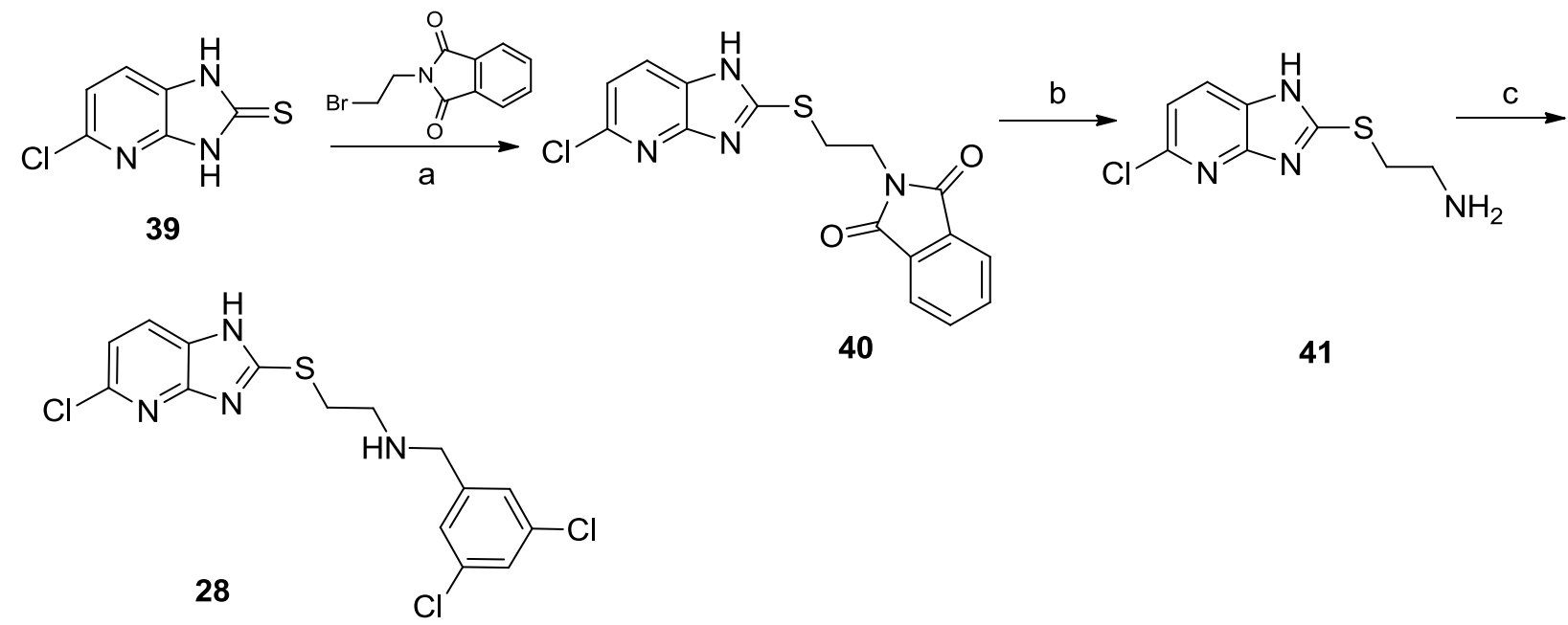

Scheme 4. Reagents and conditions: (a) $\mathrm{K}_{2} \mathrm{CO}_{3}, \mathrm{CH}_{3} \mathrm{CN}$, r.t. overnight; (b) $\mathrm{H}_{2} \mathrm{NNH}_{2}, \mathrm{CH}_{3} \mathrm{OH}$, MW, $70{ }^{\circ} \mathrm{C}, 20 \mathrm{~min}$, (c) 3,5-dichlorobenzaldehyde, $\mathrm{MeOH}, \mathrm{NaBH}_{3} \mathrm{CN}$.

Linear linker inhibitors 29 and $\mathbf{3 0}$ were prepared using the procedure shown in Scheme 5. The $1 H$-benzo[d]imidazole or $1 H$-imidazo[4,5-b]pyridine ring were generated by first reacting aryl diamines with isocyanate $\mathbf{4 2}$, followed by treatment with DIC. Target compounds 29 and $\mathbf{3 0}$ were obtained by removing the Boc protecting group with $\mathrm{HCl}$ in dioxane.

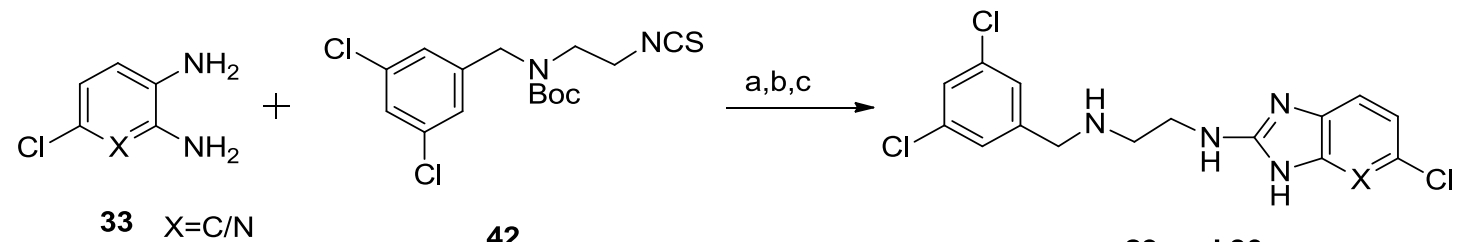

Scheme 5. Reagents and conditions: (a) $\mathrm{CH}_{3} \mathrm{CN}$, reflux, overnight; (b) DIC, $\mathrm{CH}_{3} \mathrm{CN}$, reflux, overnight; (c) $\mathrm{HCl}$, dioxane.

\section{Affinity of inhibitors for $T b$ MetRS and potency against $T$. brucei parasites}

All the compounds reported here were first assessed for binding to TbMetRS by a thermal shift assay, followed by testing in a $T$. brucei growth inhibition assay. A good correlation was observed between $\Delta \mathrm{Tm}$ and $\mathrm{EC}_{50}$, which is consistent with previous observations [8,14]. The higher the affinity the compound for the enzyme (higher $\Delta \mathrm{Tm}$ ), the more potent the compound inhibits T. brucei parasite growth. These results support the hypothesis that the compounds act on target and their cellular activity is directly related to their affinity to the target. To evaluate the potency of the inhibitors, an enzymatic ATP depletion assay was performed as described 
previously [12]. For compounds with an $\mathrm{IC}_{50}$ below $50 \mathrm{nM}$ (the enzyme concentration) the thermal shift magnitude should be used for potency ranking.

Table 1. Binding and inhibitory activity of compounds designed to investigate the benzimidazole substitution.

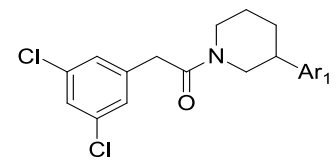

\begin{tabular}{|c|c|c|c|c|}
\hline $\begin{array}{l}\text { Compound } \\
\text { Number }\end{array}$ & $\mathbf{A r} \mathbf{r}_{1}$ & $\Delta \operatorname{Tm}\left({ }^{\circ} \mathbf{C}\right)^{\mathrm{a}}$ & $\mathrm{IC}_{50}(\mathrm{nM})^{\mathrm{b}}$ & $\mathrm{EC}_{50}(\mathrm{nM})^{\mathrm{c}}$ \\
\hline 3 & & 7.8 & 288 & $>5000$ \\
\hline 4 & & 7.4 & 926 & 8810 \\
\hline 5 & & 8.0 & 184 & 3260 \\
\hline 6 & & 7.2 & 60 & 1397 \\
\hline 7 & & - & $<50$ & 1058 \\
\hline 8 & & 7.0 & 138 & 3334 \\
\hline 9 & & 7.0 & 812 & 4603 \\
\hline
\end{tabular}

${ }^{a}$ Values are the averages of two or more experiments; ${ }^{b}$ Control for $T b M e t R S ~ \mathrm{IC}_{50}$ assay average \pm SEM:

Met-SA1 [15] (9.9 $\mathrm{nM} \pm 1.0 \mathrm{nM} ; \mathrm{n}=11$ assays); ${ }^{\mathrm{c} C o n t r o l}$ for $\mathrm{TbEC}_{50}$ assay average $\pm \mathrm{SEM}$ : Pentamidine $(0.90 \mathrm{nM} \pm 0.17 \mathrm{nM} ; \mathrm{n}=11)$.

As shown in Table 1, all the compounds designed to investigate the effect of substitution on the benzimidazole ring (or imidazopyridine) were more potent than compound $\mathbf{1}$. It was also noted that the substitution pattern on the benzimidazole ring has a significant impact on activity. Compound 3 without substitution on benzimidazole ring showed moderate enzyme inhibition with an $\mathrm{IC}_{50}$ of $288 \mathrm{nM}$ against $T b$ MetRS. Introduction of a substitution to the $\mathrm{C}-4$ of the benzimidazole ring (compound 4 ) decreased potency compared to compound $\mathbf{3}$. However, the C- 
5 substituted compounds (compounds 5-7) showed improved activity compared to 3 . Especially, both of the 5-chloro substituted compounds 6 and 7 exhibited approximately 5-fold cellular activity improvement compared to 3. Substitution at C-6 (compounds 8 and 9 ) decreased potency compared to 6. This investigation led to the discovery of 5-chloro-benzimidazole (or 5-chloroimidazopyridine) moiety as a preferred fragment for the AP.

We then focused our investigation on the linker part while maintaining the 3,5-dichlorophenyl (preferred fragment for the EMP) and the 5-chloro-benzimidazole (or 5-chloro-imidazopyridine) (preferred fragments for the AP). The compounds with different linkers are summarized in Table 2. Changing the amide of the linker to an amine gave compound 10, which decreased potency around 3-fold compared to $\mathbf{6}$. As many of the previously reported $T b$ MetRS inhibitors contain a benzyl amine group, which is believed to be important for the binding between the ligand and the target $[9,14]$, the $\mathbf{N}$ in the linker of $\mathbf{1 0}$ was shifted to a position equivalent to the benzyl position of the 3,5-dichlorophenyl ring, which resulted in compounds $\mathbf{1 1}$ and 12. Compared to compound 6, compound $\mathbf{1 1}$ did not show improvement in cellular potency though the affinity for the enzyme improved $\left(5.4{ }^{\circ} \mathrm{C}\right.$ higher $\left.\Delta \mathrm{Tm}\right)$. In contrast, compound 12 improved both cellular potency (4-fold lower $\mathrm{EC}_{50}$ ) and enzyme affinity $\left(7.0^{\circ} \mathrm{C}\right.$ higher $\Delta \mathrm{Tm}$ ) compared to $\mathbf{6}$. As compound 12 contains two chiral centers, thus a mixture of 4 stereoisomers, it is reasonable to predict that the actual isomer responsible for the activity would be more potent. Presently, we were only able to obtain one single stereoisomer $\mathbf{1 3}$ which showed slightly worse activity compared to compound 12. To reduce the number of chiral centers, the cyclohexane of $\mathbf{1 2}$ was replaced by a piperidine in compound 14 , with only one chiral center. The racemic 14 exhibited improved potency (2-fold lower $\left.\mathrm{EC}_{50}\right)$ and affinity $\left(4.2{ }^{\circ} \mathrm{C}\right.$ higher $\Delta \mathrm{Tm}$ ) compared to compound 12. After synthesis of the stereoisomers of $\mathbf{1 4}$, the $S$-isomer $\mathbf{1 6}$ was shown to be markedly more potent ( $>25$ fold lower $\mathrm{EC}_{50}$ ) with higher affinity $\left(5.9^{\circ} \mathrm{C}\right.$ higher $\Delta \mathrm{Tm}$ ) compared to the $R$-isomer $\mathbf{1 5}$, indicating that the $S$-isomer was responsible for the activity of $\mathbf{1 4}$.

Table 2. Binding and inhibitory activity of compounds designed to investigate the linkers.

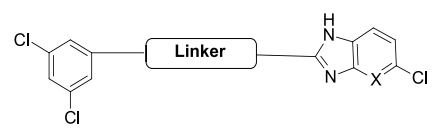

\begin{tabular}{llllll}
\hline Compound & Linker & $\mathrm{X}$ & $\Delta \mathrm{Tm}\left({ }^{\circ} \mathrm{C}\right)^{\mathrm{a}}$ & $\mathrm{IC}_{50}(\mathrm{nM})^{\mathrm{b}}$ & $\mathrm{EC}_{50}(\mathrm{nM})^{\mathrm{c}}$
\end{tabular}




\begin{tabular}{|c|c|c|c|c|c|}
\hline Number & & & & & \\
\hline 10 & & $\mathrm{~N}$ & 6.0 & $>10000$ & 3763 \\
\hline 11 & & $\mathrm{C}$ & 12.6 & 580 & 1952 \\
\hline 12 & & $\mathrm{~N}$ & 14.2 & 124 & 359 \\
\hline 13 & & $\mathrm{~N}$ & 13.1 & 106 & 580 \\
\hline 14 & & $\mathrm{~N}$ & 18.4 & $<50$ & 82 \\
\hline 15 & $\vdash_{H}$ & $\mathrm{~N}$ & 13.1 & 192 & 999 \\
\hline 16 & & $\mathrm{~N}$ & 19.0 & $<50$ & 39 \\
\hline 17 & & $\mathrm{~N}$ & 7.5 & 196 & 8802 \\
\hline 18 & & $\mathrm{~N}$ & 14.4 & $<50$ & 343 \\
\hline 19 & & $\mathrm{~N}$ & 2.6 & $>10000$ & $>20000$ \\
\hline 20 & & $\mathrm{~N}$ & 0 & $>10000$ & $>20000$ \\
\hline 21 & & $\mathrm{~N}$ & 5.8 & 4970 & 13311 \\
\hline 22 & & $\mathrm{~N}$ & 6.4 & 2166 & 15263 \\
\hline 23 & & $\mathrm{~N}$ & 7.2 & 696 & 9013 \\
\hline 24 & & $\mathrm{~N}$ & 11.4 & $<50$ & 1539 \\
\hline 25 & & $\mathrm{~N}$ & 6.8 & 682 & 1813 \\
\hline 26 & $\Upsilon_{\mathrm{H}}$ & $\mathrm{C}$ & 10.8 & 243 & 2154 \\
\hline 27 & $r_{\mathrm{H}}$ & $\mathrm{N}$ & 12.8 & $<50$ & 307 \\
\hline 28 & $r_{H}{ }_{H}^{-}$ & $\mathrm{N}$ & - & 1054 & 1399 \\
\hline 29 & $\aleph_{N} \uparrow$ & $\mathrm{N}$ & 14.5 & $<50$ & 61 \\
\hline
\end{tabular}


${ }^{\mathrm{a}}$ Values are the average of two or more experiments; ${ }^{\mathrm{b}}$ Control for $T b \mathrm{MetRS} \mathrm{IC}_{50}$ assay average $\pm \mathrm{SEM}$ :

Met-SA1 [15] (9.9 $\mathrm{nM} \pm 1.0 \mathrm{nM} ; \mathrm{n}=11$ assays $) ;{ }^{\mathrm{c}}$ Control for $T b \mathrm{EC}_{50}$ assay average $\pm \mathrm{SEM}$ : Pentamidine $(0.90 \mathrm{nM} \pm 0.17 \mathrm{nM} ; \mathrm{n}=11)$.

Based on compound 16, alternative linkers between the 3,5-dichlorophenyl moiety and the piperidine ring were investigated. Replacement of the amine by an ether resulted in compound 17. Changing the amine into two different versions of an amide furnished compounds $\mathbf{1 9}$ and $\mathbf{2 0 .}$ Unfortunately, these three compounds exhibited poorer potency. Shifting the $\mathrm{N}$ in the linker to the benzyl position gave compound 18, which showed worse affinity and potency compared to compound 14. Shifting the 3,5-dichlorophenyl moiety from the meta-position to the paraposition of the piperidine ring gave compound 21. This modification led to loss of potency, indicating the meta-substitution pattern is important for activity. In addition, the ring size of the cyclic linker was explored. A 4-member ring linker (compound 22) was detrimental. 5-member ring linker compounds were much weaker compared to compound 16, though the $S$-isomer 24 was $\sim 6$-fold more potent than the $R$-isomer 23. The 7-member ring compound 25 did not shown improvement either. Thus, the 6-member ring is the preferred cyclic linker so far.

Modifying the rigid cyclic linker into a more flexible linear linker while keeping the hydrophobic interactions established with TbMetRS residue Tyr250 would remove the chiral center and be predicted to maintain the binding affinity. The linear linker compounds 26 and 27 exhibited comparable potency compared to their equivalent cyclic linker compounds 11 and 12. Linear linker compound $\mathbf{2 9}$ was comparable to its equivalent cyclic linker compound $\mathbf{1 6}$ as well, demonstrating that the linear linker is well tolerated as a replacement of the cyclic linker. Encouragingly, introducing a methyl group to the imidazopyridine side NH group of compound 29 resulted in compound 31, which improved cellular potency ( 3 -fold lower $\left.\mathrm{EC}_{50}\right)$ and affinity (3.9 ${ }^{\circ} \mathrm{C}$ higher $\Delta \mathrm{Tm}$ ) compared to compound 29. Compound 31 was the most potent compound observed of this series.

\section{Crystal structures of $\mathrm{TbMetRS}$ in complex with compounds 16 and 31}


To check for unexpected changes in the binding mode, we obtained crystal structures of TbMetRS in complex with compounds 16 and 31. The structures were solved at 2.8 and $2.4 \AA$ resolution, respectively (Table S1). Compounds $\mathbf{1 6}$ and $\mathbf{3 1}$ bind similarly to the target protein (Figure 2). The almost perfect superposition of the linkers in compounds $\mathbf{1 6}$ and $\mathbf{3 1}$ shows that the linear linker maintained the desired conformation for compound 31, allowing the compound to interact hydrophobically with $T b$ MetRS through the two ring systems (3,5-dichlorophenyl moiety and the 5-chloro-imidazopyridine) as well as through the methylated linker. Additionally, the distance between residue Tyr250 and the methyl substituent in compound $\mathbf{3 1}(\sim 3.6 \AA)$ is more favorable than the distance between the corresponding carbon atom in the cyclic ring of compound $16(\sim 4.0 \AA)$ (Figure 2A). The void in the EMP shown in the structure of TbMetRS bound to compound 1 is now filled by compounds 16 and 31 (Figure 2B). The imidazopyridine moieties of compounds $\mathbf{1 6}$ and $\mathbf{3 1}$ are in a similar position as the corresponding group in compound 1. However, the presence of the 5-chloro substituent fills the AP better than compound 1. This $\mathrm{Cl}$ adds an interaction with TbMetRS residue Leu456 (Figure 2C).

The availability of inhibitor-bound crystal structures should also help to understand the structureactivity relationship (SAR) data generated in Tables 1 and 2 in order to guide future inhibitor design. Note that in the SAR tables, some enzyme inhibition data were shown as $<50 \mathrm{nM}$ because the enzyme concentration used for the activity assay was $50 \mathrm{nM}$ (see Experimental Procedures section). Therefore, for compounds with $\mathrm{IC}_{50}<50 \mathrm{nM}$, enzyme inhibition data only confirms on-target inhibitory potency but is not useful for quantitative SAR analysis. Fortunately, the thermal shift data as an affinity gauge is available for most compounds. In fact, as observed previously $[8,14]$, there is an excellent linear correlation between $\Delta \mathrm{Tm}$ and $\mathrm{pEC}_{50}(-$ $\left.\log \mathrm{EC}_{50}\right)$ for data in Tables 1 and $2\left(\mathrm{R}^{2}=0.84\right.$ for linear regression). Given that compounds 16 and 31, the most potent inhibitors in the two chemical series under study, have essentially the same binding modes toward TbMetRS, one may assume that these two compounds present the optimal binding modes in occupying the EMP and the AP pockets while having the least strain in the ring- or linear-linker regions. Therefore, the binding modes of $\mathbf{1 6}$ and $\mathbf{3 1}$ can be used as the starting points for comparison to molecular docking studies of other inhibitors described in this work to check for deviations in binding poses inside the EMP and the AP pockets, or in energetic strains of the linker, and the correlation to $\Delta \mathrm{Tm}$ and $\mathrm{EC}_{50}$ data. New designs of $T b \mathrm{MetRS}$ 
inhibitors that can reduce linker strains and preserve optimal interactions at the EMP and the AP pockets might lead to further improvements in affinity.
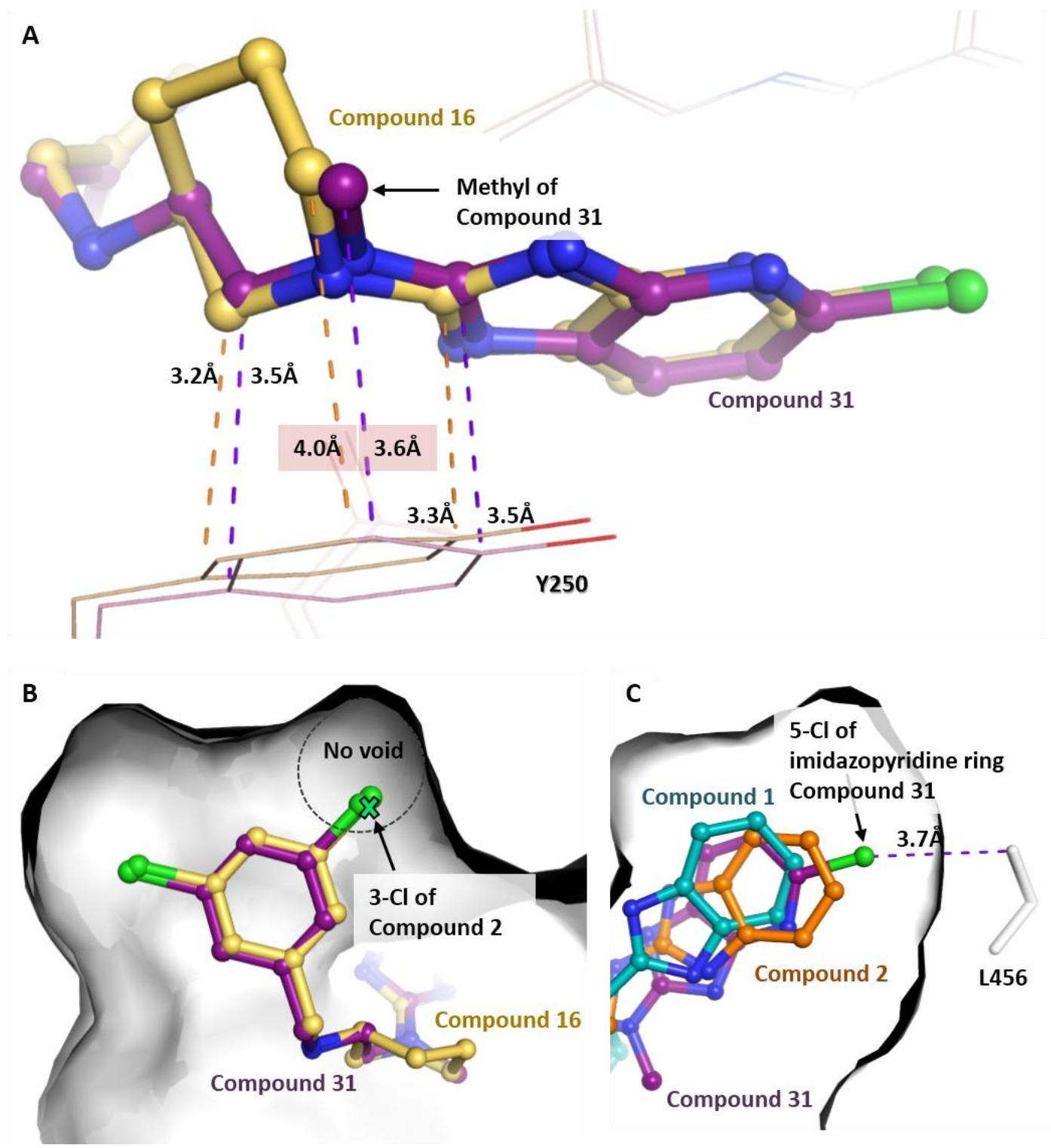

Figure 2. Crystal structures of compounds 16 and 31 in complex with TbMetRS. (A) Interactions between the linker of compounds 16 (yellow) and $\mathbf{3 1}$ (magenta) and the protein residue Tyr250; (B) 3,5dichlorophenyl ring of compounds $\mathbf{1 6}$ and $\mathbf{3 1}$ bound to the EMP of the superimposed TbMetRS•inhibitor structures; (C) Benzimidazole or imidazopyridine ring of compounds $\mathbf{1}$ (cyan), $\mathbf{2}$ (gold) and $\mathbf{3 1}$ (magenta) bound to the AP of the superimposed TbMetRS•inhibitor structures. 


\section{Selectivity and toxicity of select inhibitors}

With novel potent inhibitors in hand, we selected a group of compounds to examine their selectivity and toxicity. The selected compounds were tested for host cell toxicity using a human lymphoblast cell line (CRL-8155) and a hepatocellular carcinoma cell line (Hep G2) (Table 3). These compounds exhibited low toxicities to mammalian cell lines with $\mathrm{EC}_{50} \mathrm{~s}$ ranging from 9.9 to $>50 \mu \mathrm{M}$. The most potent compounds on T. brucei (16 and 31) exhibited high selectivity indices of 759 and 1027, respectively.

Table 3. Host cell toxicity data of select inhibitors.

\begin{tabular}{cccccc}
\hline $\begin{array}{c}\text { Compound } \\
\text { Number }\end{array}$ & $\begin{array}{c}\mathbf{C R L - 8 1 5 5}^{\mathrm{a}} \\
\mathbf{E C}_{\mathbf{5 0}}(\boldsymbol{\mu M})\end{array}$ & $\begin{array}{c}\mathbf{H e p ~ G 2}^{\mathrm{b}} \\
\mathbf{E C}_{\mathbf{5 0}}(\boldsymbol{\mu M})\end{array}$ & $\begin{array}{c}\text { Compound } \\
\text { Number }\end{array}$ & $\begin{array}{c}\mathbf{C R L - 8 1 5 5}^{\mathrm{a}} \\
\mathbf{E C}_{\mathbf{5 0}}(\boldsymbol{\mu M})\end{array}$ & $\begin{array}{c}\mathbf{H e p ~ G 2 ~}^{\mathrm{b}} \\
\mathbf{E C}_{\mathbf{5 0}}(\boldsymbol{\mu M})\end{array}$ \\
\hline $\mathbf{6}$ & 22.8 & 35.4 & $\mathbf{2 7}$ & 45.7 & 45.6 \\
$\mathbf{1 2}$ & 33.1 & 32.3 & $\mathbf{2 9}$ & 33.8 & 45.9 \\
$\mathbf{1 4}$ & 46.2 & $>50.0$ & $\mathbf{3 0}$ & 14.0 & 9.9 \\
$\mathbf{1 6}$ & 29.3 & 49.0 & $\mathbf{3 1}$ & 22.6 & 39.2 \\
$\mathbf{1 8}$ & 15.4 & 29.2 & & & \\
\hline
\end{tabular}

${ }^{\mathrm{a}}$ Control for CRL-8155 EC 50 assay average \pm SEM: Quinacrine $(2.12 \mu \mathrm{M} \pm 0.3 \mu \mathrm{M} ; \mathrm{n}=5) ;{ }^{\mathrm{b}}$ Control for HepG2 $\mathrm{EC}_{50}$ assay average \pm SEM: Quinacrine $(11.9 \mu \mathrm{M} \pm 0.6 \mu \mathrm{M} ; \mathrm{n}=4)$.

\section{Pharmacokinetic and permeability of compounds 16 and 31}

Compounds 16 and $\mathbf{3 1}$ were also subjected to PK studies in mice following oral administration at $50 \mathrm{mg} / \mathrm{kg}$. Compound 16 exhibited outstanding PK properties, showing a Cmax at $37.6 \mu \mathrm{M}$, and a AUC of $6223 \mathrm{~min}^{*} \mu \mathrm{mol} / \mathrm{L}$. Compound 31 exhibited promising PK properties with Cmax at $9.7 \mu \mathrm{M}$ and AUC of $952 \mathrm{~min}^{*} \mu \mathrm{mol} / \mathrm{L}$.

The potential permeability of compounds to the CNS is important for treating late stage HAT. Hence, compounds 16 and 31 were tested for brain permeability in mice at a dose of $5 \mathrm{mg} / \mathrm{kg} \mathrm{IP}$. Comparing plasma with brain tissue concentrations at a single time-point (60 min), the cyclic linker compound $\mathbf{1 6}$ was observed to have poor permeability, with nearly undetectable brain levels at $60 \mathrm{~min}$ after IP injection. This permeability result suggests that the cyclic-linker compound is unlikely to pass through the blood-brain barrier, thus makes it a poor candidate for treating HAT. In contrast, the linear linker compound $\mathbf{3 1}$ exhibited good permeability, with brain/plasma ratio of 0.27 at $60 \mathrm{~min}$ after IP injection. This feature makes compound $\mathbf{3 1}$ a promising lead compound for developing therapies for treating late stage HAT. 


\section{CONCLUSIONS}

In summary, starting with a weak screening hit 1, two new series of potent T. brucei methionyl tRNA synthetase inhibitors were obtained through structure-guided design. The best compounds $\mathbf{1 6}$ in the cyclic-linker series and $\mathbf{3 1}$ in the linear-linker series were potent in a T. brucei growth inhibition assay, with $\mathrm{EC}_{50} \mathrm{~s}$ of 39 and $22 \mathrm{nM}$, respectively. These compounds also showed low toxicity to the mammalian cells, resulting in a high selectivity index. Compound $\mathbf{1 6}$ exhibited outstanding PK properties but poor brain permeability, therefore further investigations are ongoing with the aim to improve its permeability. Compound 31 exhibited good PK properties and, importantly, it showed moderately good brain penetration in mice. These studies provide novel lead compounds for developing drugs for treating HAT.

\section{EXPERIMENTAL PROCEDURES}

\section{General Chemistry}

Unless otherwise stated, all chemicals were purchased from commercial suppliers and used without further purification. Microwave irradiation was performed on a CEM Discover System. Reaction progress was monitored by thin-layer chromatograph on silica gel containing an inert binder and a fluorescent indicator (activated at $254 \mathrm{~nm}$ ) coated flexible sheet (J. T. Baker). Chromatography was performed using an automated flash chromatography system, eluting on pre-packed silica gel columns with $\mathrm{CH}_{2} \mathrm{Cl}_{2} / \mathrm{MeOH}$ or cyclohexane/Ethyl acetate gradient solvent system. The purification by preparative RP-HPLC was performed on Waters Xterra Prep RP18 OBD $5 \mu \mathrm{M}(19 \mathrm{~mm} \times 50 \mathrm{~mm})$, eluting with a $\mathrm{CH}_{3} \mathrm{CN} / \mathrm{H}_{2} \mathrm{O}$ solvent system with $0.1 \%$ TFA. The purity of all final compounds was determined by analytical LCMS using an Onyx Monolithic C18 column (4.6 mm x $100 \mathrm{~mm}$ ) (Phenomenex, Torrance, CA) and eluting with $\mathrm{CH}_{3} \mathrm{CN}_{2} \mathrm{H}_{2} \mathrm{O}$ solvent system (+0.1\% TFA). The products were detected by UV at $220 \mathrm{~nm}$. All compounds were determined to be $>95 \%$ pure by this method. The mass spectra were recorded with an Ion Trap Mass Spectrometer (Agilent, Santa Clara, CA). NMR spectra were recorded on Bruker 300 or $500 \mathrm{MHz}$ spectrometers at ambient temperature. Chemical shifts are reported in parts per million $(\delta)$ referenced to the internal standards $\left(7.26 \mathrm{ppm}\right.$ for $\mathrm{CDCl}_{3}, 3.34 \mathrm{ppm}$ for $\mathrm{CD}_{3} \mathrm{OD}$ and $2.50 \mathrm{ppm}$ for $\left(\left(\mathrm{CD}_{3}\right)_{2} \mathrm{SO}\right)$ and coupling constants in $\mathrm{Hz}$.

General procedures for the synthesis of compounds $3-13$ and 26 (Scheme 1). 
(a) Substituted carboxylic acid 32 (1 eq) and aromatic diamine 33 (1 eq) in pyridine was added EDC (1.5 eq). The mixture was stirred at r.t. overnight, and pyridine was then removed under reduced pressure. After addition of saturated aqueous sodium bicarbonate to the residue, the mixture was extracted with EA. The organic layer was dried over anhydrous sodium sulfate, and concentrated in vacuum. Purification through flash chromatography on silica gel eluted with MeOH-DCM (0.5\% ammonia hydroxide) gave the amide intermediate 34 .

(b) When $\mathrm{X}=\mathrm{C}$ : The amide intermediate 34 (1 eq) was dissolved in glacial acetic acid and heated at $60{ }^{\circ} \mathrm{C}$ for 3 hours. The reaction was concentrated in vacuum and the residue partitioned between saturated sodium bicarbonate and DCM. The organic extract was dried over anhydrous sodium sulfate, and concentrated in vacuum. Purification through flash chromatography on silica gel eluted with MeOH-DCM (0.5\% ammonia hydroxide) gave target compound.

When $\mathrm{X}=\mathrm{N}$ : The amide intermediate 34 was dissolved in glacial acetic acid, $\mathrm{POCl}_{3}$ (3 eq) was added, the mixture was microwave irradiated at $150{ }^{\circ} \mathrm{C}$ for 1 hour. The reaction was concentrated in vacuum and the residue partitioned between saturated sodium bicarbonate and DCM. The organic extract was dried over anhydrous sodium sulfate, and concentrated in vacuum. The residue was purified through flash chromatography on silica gel eluted with MeOH-DCM (0.5\% ammonia hydroxide) to give the target compound.

Compound 3: 1-(3-(1H-benzo[d]imidazol-2-yl)piperidin-1-yl)-2-(3,5-dichlorophenyl) ethanone was synthesized using 1-(2-(3, 5-dichlorophenyl)acetyl)piperidine-3-carboxylic acid and benzene-1,2-diamine. ${ }^{1} \mathrm{H}$ NMR (500 MHz, MeOD) $\delta$ 7.85-7.71 (m, 2H), 7.67-7.54 (m, 2H), $7.31(\mathrm{~s}, 1 \mathrm{H}), 7.27-7.21(\mathrm{~m}, 2 \mathrm{H}), 4.74(\mathrm{~d}, J=12.0 \mathrm{~Hz}, 1 \mathrm{H}), 4.03$ (d, $J=13.7 \mathrm{~Hz}, 1 \mathrm{H}), 3.96-3.89$ $(\mathrm{m}, 1 \mathrm{H}), 3.86(\mathrm{~d}, J=3.9 \mathrm{~Hz}, 2 \mathrm{H}), 3.44-3.33(\mathrm{~m}, 2 \mathrm{H}), 2.47-2.30(\mathrm{~m}, 1 \mathrm{H}), 2.12$ (dt, $J=13.7,7.0$ $\mathrm{Hz}, 1 \mathrm{H}), 1.93-1.79(\mathrm{~m}, 1 \mathrm{H}), 1.76-1.58(\mathrm{~m}, 1 \mathrm{H}) . \mathrm{MS}(\mathrm{ESI})(\mathrm{M}+\mathrm{H})^{+}=389.1$. HPLC analysis: $99.0 \%$ purity.

Compound 4: 1-(3-(4-chloro-1H-benzo[d]imidazol-2-yl)piperidin-1-yl)-2-(3,5-dichlorophenyl) ethanone was synthesized using 1-(2-(3, 5-dichlorophenyl)acetyl)piperidine-3-carboxylic acid and 3-chlorobenzene-1,2-diamine. ${ }^{1} \mathrm{H} \mathrm{NMR}\left(500 \mathrm{MHz}, \mathrm{CDCl}_{3}\right) \delta 7.55(\mathrm{~s}, 1 \mathrm{H}), 7.47(\mathrm{~d}, J=8.6$ $\mathrm{Hz}, 1 \mathrm{H}), 7.20(\mathrm{dd}, J=8.6,1.8 \mathrm{~Hz}, 1 \mathrm{H}), 7.16(\mathrm{~d}, J=5.4 \mathrm{~Hz}, 1 \mathrm{H}), 7.01(\mathrm{~d}, J=1.1 \mathrm{~Hz}, 2 \mathrm{H}), 4.39$ $(\mathrm{dd}, J=13.6,4.2 \mathrm{~Hz}, 1 \mathrm{H}), 3.74(\mathrm{~d}, J=13.8 \mathrm{~Hz}, 1 \mathrm{H}), 3.68(\mathrm{~d}, J=6.9 \mathrm{~Hz}, 2 \mathrm{H}), 3.66-3.59(\mathrm{~m}$, 
1H), 3.48-3.38 (m, 1H), 3.36-3.26 (m, 1H), 2.70-2.59 (m, 1H), 2.18-2.07 (m, 1H), 1.65-1.52 $(\mathrm{m}, 1 \mathrm{H}), 1.45-1.31(\mathrm{~m}, 1 \mathrm{H})$. MS $(\mathrm{ESI})(\mathrm{M}+\mathrm{H})^{+}=423.6$. HPLC analysis: $>99.9 \%$ purity.

Compound 5: 2-(3,5-dichlorophenyl)-1-(3-(5-fluoro-1H-benzo[d]imidazol-2-yl)piperidin-1yl)ethanone was synthesized using 1-(2-(3, 5-dichlorophenyl)acetyl)piperidine-3-carboxylic acid and 4-fluorobenzene-1,2-diamine. ${ }^{1} \mathrm{H} \mathrm{NMR}\left(500 \mathrm{MHz}, \mathrm{CDCl}_{3}\right) \delta 7.48(\mathrm{dd}, J=8.6,4.5 \mathrm{~Hz}, 1 \mathrm{H})$, $7.26(\mathrm{dd}, J=9.0,1.8 \mathrm{~Hz}, 1 \mathrm{H}), 7.19(\mathrm{~s}, 1 \mathrm{H}), 7.04$ (s, 2H), $7.00(\mathrm{td}, J=9.2,2.2 \mathrm{~Hz}, 1 \mathrm{H}), 4.29$ (dd, $J=13.7,5.3 \mathrm{~Hz}, 1 \mathrm{H}), 3.84(\mathrm{dd}, J=14.1,3.2 \mathrm{~Hz}, 1 \mathrm{H}), 3.72(\mathrm{~d}, J=6.6 \mathrm{~Hz}, 2 \mathrm{H}), 3.65-3.56(\mathrm{~m}$, $1 \mathrm{H}), 3.54-3.49(\mathrm{~m}, 1 \mathrm{H}), 3.34-3.22(\mathrm{~m}, 1 \mathrm{H}), 2.61$ (dt, $J=10.4,6.0 \mathrm{~Hz}, 1 \mathrm{H}), 2.17$ (qd, $J=8.6,3.9$ $\mathrm{Hz}, 1 \mathrm{H}), 1.67-1.52(\mathrm{~m}, 1 \mathrm{H}), 1.50-1.44(\mathrm{~m}, 1 \mathrm{H}) . \mathrm{MS}(\mathrm{ESI})(\mathrm{M}+\mathrm{H})^{+}=407.8$. HPLC analysis: 99.8 $\%$ purity.

Compound 6: 1-(3-(5-chloro-1H-benzo[d]imidazol-2-yl) piperidin-1-yl)-2-(3,5-dichlorophenyl) ethanone was synthesized using 1-(2-(3, 5-dichlorophenyl)acetyl)piperidine-3-carboxylic acid and 4-chlorobenzene-1,2-diamine. ${ }^{1} \mathrm{H}$ NMR $\left(500 \mathrm{MHz}, \mathrm{CDCl}_{3}\right) \delta 7.52(\mathrm{~s}, 1 \mathrm{H}), 7.44(\mathrm{~d}, J=7.3$ Hz, 1H), 7.19-7.11 (m, 2H), 7.00 (s, 2H), 4.35 (d, J = 11.2 Hz, 1H), 3.77-3.70 (m, 1H), 3.68 (d, $J=6.9 \mathrm{~Hz}, 2 \mathrm{H}), 3.65-3.56(\mathrm{~m}, 1 \mathrm{H}), 3.44(\mathrm{t}, J=11.2 \mathrm{~Hz}, 1 \mathrm{H}), 3.27(\mathrm{~s}, 1 \mathrm{H}), 2.65-2.54(\mathrm{~m}, 1 \mathrm{H})$, $2.12(\mathrm{dd}, J=16.0,7.0 \mathrm{~Hz}, 1 \mathrm{H}), 1.62-1.49(\mathrm{~m}, 1 \mathrm{H}), 1.44-1.34(\mathrm{~m}, 1 \mathrm{H}) . \mathrm{MS}(\mathrm{ESI})(\mathrm{M}+\mathrm{H})^{+}=$ 423.6. HPLC analysis: $98.5 \%$ purity.

Compound 7: 1-(3-(5-chloro-1H-imidazo[4,5-b]pyridin-2-yl)piperidin-1-yl)-2-(3,5dichlorophenyl)ethanone was synthesized using 1-(2-(3, 5-dichlorophenyl)acetyl)piperidine-3carboxylic acid and 6-chloropyridine-2,3-diamine. ${ }^{1} \mathrm{H}$ NMR $\left(500 \mathrm{MHz}, \mathrm{CDCl}_{3}\right) \delta 7.92(\mathrm{~d}, J=8.2$ $\mathrm{Hz}, 1 \mathrm{H}), 7.35-7.31(\mathrm{~m}, 1 \mathrm{H}), 7.21(\mathrm{~d}, J=8.3 \mathrm{~Hz}, 1 \mathrm{H}), 7.19-7.15(\mathrm{~m}, 2 \mathrm{H}), 4.18$ (dd, $J=13.5,5.4$ $\mathrm{Hz}, 1 \mathrm{H}), 3.93(\mathrm{dd}, J=13.7,2.7 \mathrm{~Hz}, 1 \mathrm{H}), 3.72$ (d, $J=8.1 \mathrm{~Hz}, 2 \mathrm{H}), 3.62-3.47$ (m, 2H), 3.30-3.18 (m, 1H), $2.56(\mathrm{ddd}, J=13.2,11.0,6.7 \mathrm{~Hz}, 1 \mathrm{H}), 2.17(\mathrm{ddd}, J=13.2,8.5,4.1 \mathrm{~Hz}, 1 \mathrm{H}), 1.64-1.54$ $(\mathrm{m}, 1 \mathrm{H}), 1.55-1.43(\mathrm{~m}, 1 \mathrm{H})$. MS (ESI) $(\mathrm{M}+\mathrm{H})^{+}=424.5$. HPLC analysis: $95.0 \%$ purity.

Compound 8: 1-(3-(5-chloro-6-fluoro-1H-benzo[d]imidazol-2-yl)piperidin-1-yl)-2-(3,5dichlorophenyl)ethanone was synthesized using 1-(2-(3, 5-dichlorophenyl)acetyl)piperidine-3carboxylic acid and 4-chloro-5-fluorobenzene-1,2-diamine. ${ }^{1} \mathrm{H}$ NMR (500 $\left.\mathrm{MHz}, \mathrm{CDCl}_{3}\right) \delta 7.55$ $(\mathrm{d}, J=6.4 \mathrm{~Hz}, 1 \mathrm{H}), 7.32$ (d, $J=9.0 \mathrm{~Hz}, 1 \mathrm{H}), 7.14(\mathrm{~s}, 1 \mathrm{H}), 7.00$ (s, 2H), 4.31 (dd, $J=14.7,5.1$ Hz, 1H), 3.75 (dd, $J=12.5,10.2 \mathrm{~Hz}, 1 \mathrm{H}), 3.69$ (d, $J=4.5 \mathrm{~Hz}, 2 \mathrm{H}), 3.66-3.56$ (m, 1H), 3.51- 
$3.42(\mathrm{~m}, 1 \mathrm{H}), 3.31-3.23(\mathrm{~m}, 1 \mathrm{H}), 2.66-2.54(\mathrm{~m}, 1 \mathrm{H}), 2.18-2.10(\mathrm{~m}, 1 \mathrm{H}), 1.63-1.53(\mathrm{~m}, 1 \mathrm{H})$, $1.39(\mathrm{dt}, J=12.9,9.2 \mathrm{~Hz}, 1 \mathrm{H})$. MS (ESI) $(\mathrm{M}+\mathrm{H})^{+}=441.6$. HPLC analysis: $96.6 \%$ purity.

Compound 9: $\quad 1$-(3-(5,6-dichloro-1H-benzo[d] imidazol-2-yl)piperidin-1-yl)-2-(3,5dichlorophenyl)ethanone was synthesized using 1-(2-(3, 5-dichlorophenyl)acetyl)piperidine-3carboxylic acid and 4,5-dichlorobenzene-1,2-diamine. ${ }^{1} \mathrm{H}$ NMR $\left(500 \mathrm{MHz}, \mathrm{CDCl}_{3}\right) \delta 7.66(\mathrm{~s}$, 2H), $7.16(\mathrm{~s}, 1 \mathrm{H}), 7.01(\mathrm{~s}, 2 \mathrm{H}), 4.36(\mathrm{dd}, J=13.3,3.8 \mathrm{~Hz}, 1 \mathrm{H}), 3.76-3.70(\mathrm{~m}, 1 \mathrm{H}), 3.70-3.67(\mathrm{~m}$, $1 \mathrm{H}), 3.64(\mathrm{~d}, J=13.6 \mathrm{~Hz}, 1 \mathrm{H}), 3.46$ (t, $J=10.2 \mathrm{~Hz}, 1 \mathrm{H}), 3.38-3.27(\mathrm{~m}, 1 \mathrm{H}), 2.64$ (dd, $J=13.4$, $4.7 \mathrm{~Hz}, 1 \mathrm{H}), 2.15(\mathrm{dd}, J=13.5,9.9 \mathrm{~Hz}, 1 \mathrm{H}), 1.66-1.54(\mathrm{~m}, 1 \mathrm{H}), 1.43-1.31(\mathrm{~m}, 1 \mathrm{H})$. MS (ESI) $(\mathrm{M}+\mathrm{H})^{+}=457.4$. HPLC analysis: $99.6 \%$ purity.

Compound 10: 5-chloro-2-(1-(3,5-dichlorophenethyl)piperidin-3-yl)-1H-imidazo[4,5-b]pyridine was synthesized using 1-(3,5-dichlorophenethyl)piperidine-3-carboxylic acid and 6chloropyridine-2,3-diamine. ${ }^{1} \mathrm{H}$ NMR $(500 \mathrm{MHz}, \mathrm{MeOD}) \delta 8.08(\mathrm{~d}, J=8.3 \mathrm{~Hz}, 1 \mathrm{H}), 7.47(\mathrm{~d}, J=$ $8.3 \mathrm{~Hz}, 1 \mathrm{H}), 7.44-7.35(\mathrm{~m}, 3 \mathrm{H}), 4.10(\mathrm{~d}, J=11.4 \mathrm{~Hz}, 1 \mathrm{H}), 3.86-3.71(\mathrm{~m}, 2 \mathrm{H}), 3.56-3.47(\mathrm{~m}$, $3 \mathrm{H}), 3.26-3.14(\mathrm{~m}, 3 \mathrm{H}), 2.42(\mathrm{~d}, J=11.4 \mathrm{~Hz}, 1 \mathrm{H}), 2.29-2.18(\mathrm{~m}, 1 \mathrm{H}), 2.18-2.05(\mathrm{~m}, 1 \mathrm{H}), 2.04-$ $1.90(\mathrm{~m}, 1 \mathrm{H})$. MS (ESI) $(\mathrm{M}+\mathrm{H})^{+}=424.5$. HPLC analysis: $>99.9 \%$ purity.

Compound 11: 3-(5-chloro-1H-benzo[d]imidazol-2-yl)-N-(3,5-dichlorobenzyl)cyclohexanamine was synthesized using 3-((tert-butoxycarbonyl)(3,5-dichlorobenzyl)amino) cyclohexane carboxylic acid and 4-chlorobenzene-1,2-diamine. ${ }^{1} \mathrm{H}$ NMR (500 MHz, $\left.\mathrm{CDCl}_{3}\right) \delta$ 7.50-7.43 (br, $1 \mathrm{H}), 7.38(\mathrm{~d}, J=6.3 \mathrm{~Hz}, 1 \mathrm{H}), 7.42-7.35(\mathrm{~m}, 3 \mathrm{H}), 7.16(\mathrm{dd}, J=8.5,1.7 \mathrm{~Hz}, 1 \mathrm{H}), 3.85(\mathrm{~s}, 2 \mathrm{H})$, $3.10(\mathrm{~s}, 1 \mathrm{H}), 2.85(\mathrm{~s}, 1 \mathrm{H}), 2.33$ (d, $J=12.4 \mathrm{~Hz}, 2 \mathrm{H}), 2.01(\mathrm{~s}, 2 \mathrm{H}), 2.00-1.90(\mathrm{~m}, 1 \mathrm{H}), 1.87-1.78$ (m, 1H), $1.74(\mathrm{dd}, J=21.6,9.0 \mathrm{~Hz}, 1 \mathrm{H}), 1.63(\mathrm{dd}, J=21.6,9.0 \mathrm{~Hz}, 1 \mathrm{H}), 1.51-1.37$ (m, 2H). MS (ESI) $(\mathrm{M}+\mathrm{H})^{+}=409.5$. HPLC analysis: $95.6 \%$ purity.

Compound 12: 3-(5-chloro-1H-imidazo[4,5-b]pyridin-2-yl)-N-(3,5-dichlorobenzyl) cyclohexanamine was synthesized using 3-((tert-butoxycarbonyl)(3,5-dichlorobenzyl)amino)cyclohexane carboxylic acid and 6-chloropyridine-2,3-diamine. ${ }^{1} \mathrm{H}$ NMR (500 MHz, MeOD) $\delta 8.21$ (t, $J=8.6$ $\mathrm{Hz}, 1 \mathrm{H}), 7.67-7.60(\mathrm{~m}, 3 \mathrm{H}), 7.60-7.54(\mathrm{~m}, 1 \mathrm{H}), 4.34(\mathrm{~s}, 2 \mathrm{H}), 3.59-3.52(\mathrm{~m}, 1 \mathrm{H}), 3.51-3.41(\mathrm{~m}$, 1H), 2.83-2.73 (m, 1H), $2.35(\mathrm{~d}, J=10.5 \mathrm{~Hz}, 1 \mathrm{H}), 2.27(\mathrm{~d}, J=11.7 \mathrm{~Hz}, 1 \mathrm{H}), 2.16(\mathrm{~d}, J=11.5$ $\mathrm{Hz}, 1 \mathrm{H}), 2.07-1.93(\mathrm{~m}, 1 \mathrm{H}), 1.71(\mathrm{~m}, 3 \mathrm{H}) . \mathrm{MS}(\mathrm{ESI})(\mathrm{M}+\mathrm{H})^{+}=410.5$; HPLC analysis: $96.0 \%$ purity. 
Compound 13: (1R,3S)-3-(5-chloro-1H-imidazo[4,5-b]pyridin-2-yl)-N-(3,5-dichlorobenzyl) cyclohexanamine was synthesized using (1S,3R)-3-((tert-butoxycarbonyl)(3,5dichlorobenzyl)amino)cyclohexane carboxylic acid and 6-chloropyridine-2,3-diamine. ${ }^{1} \mathrm{H}$ NMR (500 MHz, CDCl3) $\delta 8.05-7.88(\mathrm{br}, 1 \mathrm{H}), 7.26(\mathrm{~s}, 1 \mathrm{H}), 7.25-7.23(\mathrm{~m}, 2 \mathrm{H}), 7.22(\mathrm{~s}, 1 \mathrm{H}), 3.83(\mathrm{dd}$, $J=33.3,13.8 \mathrm{~Hz}, 2 \mathrm{H}), 3.20(\mathrm{t}, J=10.4,1 \mathrm{H}), 2.74(\mathrm{t}, J=10.4,1 \mathrm{H}), 2.42(\mathrm{~d}, J=12.5 \mathrm{~Hz}, 1 \mathrm{H})$, 2.18-2.10 (m, 1H), 2.09-1.97(m, 1H), 1.96-1.87 (m, 1H), 1.74-1.62 (m, 2H), 1.49 (td, $J=12.0$, $3.4 \mathrm{~Hz}, 1 \mathrm{H}), 1.27(\mathrm{dd}, J=16.4,9.3 \mathrm{~Hz}, 1 \mathrm{H})$. MS (ESI) $(\mathrm{M}+\mathrm{H})^{+}=410.5$; HPLC analysis: $>99.9 \%$ purity.

Compound 26: 3-(6-chloro-1H-benzo[d] imidazol-2-yl)-N-(3, 5-dichlorobenzyl) propan-1-amine in $\mathrm{HCl}$ salt form. The key intermediate tert-butyl (3-(6-chloro-1H-benzo[d]imidazol-2yl)propyl)carbamate for the synthesis of $\mathbf{2 6}$ was synthesized using 4-((tertbutoxycarbonyl)amino) butanoic acid and 4-chlorobenzene-1,2-diamine. The target compound was synthesized using tert-butyl (3-(6-chloro-1H-benzo[d]imidazol-2-yl)propyl)carbamate. ${ }^{1} \mathrm{H}$ NMR (500 MHz, MeOD) $\delta 7.91(\mathrm{~d}, J=8.3 \mathrm{~Hz}, 1 \mathrm{H}), 7.42-7.36(\mathrm{~m}, 3 \mathrm{H}), 7.33-7.27$ (m, 2H), 4.01 (s, 2H), $3.01(\mathrm{t}, J=7.2 \mathrm{~Hz}, 2 \mathrm{H}), 2.81(\mathrm{t}, J=6.6 \mathrm{~Hz}, 2 \mathrm{H}), 2.12-2.08(\mathrm{~m}, 2 \mathrm{H}) . \mathrm{MS}$ : (ESI) $(\mathrm{M}+\mathrm{H})^{+}=369.6$. HPLC analysis: $97.5 \%$ purity.

\section{General procedures for the synthesis of compounds $14-25$ and 31 (Scheme 2).}

(a) Compound 2-bromo-5-chloro-1H-imidazo[4,5-b]pyridine 35 (1 eq) was dissolved in pyridine, substituted amine 36 ( 3 eq) was added and the reaction mixture was microwave irradiated at $100{ }^{\circ} \mathrm{C}$ for $30 \mathrm{~min}$. The reaction mixture was concentrated in vacuum and the residue partitioned between saturated sodium bicarbonate and DCM. The organic extract was dried over anhydrous sodium sulfate, and concentrated in vacuum. The residue was purified through flash chromatography on silica gel eluted with $\mathrm{MeOH} / \mathrm{DCM}$ ( $0.5 \%$ ammonia hydroxide) to give intermediate 37 .

(b) When necessary, the intermediate $\mathbf{3 7}$ obtained from above step was dissolved in DCM, the solution was cooled to $0{ }^{\circ} \mathrm{C}$, then TFA (5 eq) was added dropwise. The mixture was stirred at r.t. overnight, the solvent was removed in vacuum. $\mathrm{HCl}$ in methanol was added to the residue, and the solvent was removed to give the $\mathrm{HCl}$ salt intermediate. 
(c) The $\mathrm{HCl}$ salt intermediate obtained above was dissolved in $\mathrm{CH}_{3} \mathrm{OH}$, DIPEA (1.2 eq) was added and the solution was stirred at r.t. for $10 \mathrm{~min}$. Then 3,5-dichlorobenzaldehyde(1.2 eq) was added, following by adding $\mathrm{AcOH}$ (2 eq) and $\mathrm{NaBH}_{3} \mathrm{CN}$ (2eq). The mixture was stirred at r.t. overnight. The solvent was removed under reduced pressure and the residue was extracted by DCM. The organic phase was dried over sodium sulfate. Solvent removal in vacuum and purification through flash chromatography on silica gel with $\mathrm{MeOH}-\mathrm{DCM}(0.5 \%$ ammonia hydroxide) elution gave the target compound.

Compound 14: 1-(5-chloro-1H-imidazo[4,5-b]pyridin-2-yl)-N-(3,5-dichlorobenzyl)piperidin-3amine was synthesized using tert-butyl piperidin-3-ylcarbamate. ${ }^{1} \mathrm{H}$ NMR $\left(500 \mathrm{MHz}, \mathrm{CDCl}_{3}\right) \delta$ 7.65-7.37 (br, 1H), 7.19 (s, 1H), 7.12 (s, 2H), 7.08-6.84 (br, 1H), 4.20-3.95 (br, 1H), 3.91-3.77 (br, 1H), 3.71 (s, 2H), 3.34-2.87 (m, 1H), 2.77 (s, 1H), 2.02-1.91 (m, 1H), 1.90-1.77 (m, 1H), $1.68-1.50(\mathrm{~m}, 1 \mathrm{H}), 1.50-1.33(\mathrm{~m}, 2 \mathrm{H})$. MS (ESI) $(\mathrm{M}+\mathrm{H})^{+}=411.7$; HPLC analysis: $99.6 \%$ purity.

Compound 15: (R)-1-(5-chloro-1H-imidazo[4,5-b]pyridin-2-yl)-N-(3,5-dichlorobenzyl) piperidin-3-amine was synthesized using (R)-tert-butyl piperidin-3-ylcarbamate. ${ }^{1} \mathrm{H}$ NMR (500 $\mathrm{MHz}, \mathrm{CDCl} 3) \delta$ 7.64-7.43 (br, 1H), 7.21 (t, $J=1.8 \mathrm{~Hz}, 1 \mathrm{H}), 7.15-7.09$ (m, 2H), 7.07-6.78 (br, 1H), 4.32-4.02(br, 1H), 4.02-3.78 (br, 1H), 3.73 (s, 2H), 3.39-2.89 (m, 2H), 2.89-2.63 (br, 1H), 2.09-1.92 (m, 1H), 1.91-1.74 (m, 1H), 1.73-1.52 (m, 1H), 1.54-1.32 (m, 1H). MS (ESI) $(\mathrm{M}+\mathrm{H})^{+}=412.0$; HPLC analysis: $>99.9 \%$ purity.

Compound 16: (S)-1-(5-chloro-1H-imidazo[4,5-b]pyridin-2-yl)-N-(3,5-dichlorobenzyl) piperidin-3-amine was synthesized using (S)-tert-butyl piperidin-3-ylcarbamate. ${ }^{1} \mathrm{H}$ NMR (500 $\left.\mathrm{MHz}, \mathrm{CDCl}_{3}\right) \delta 7.64-7.43(\mathrm{br}, 1 \mathrm{H}), 7.21(\mathrm{t}, J=1.8 \mathrm{~Hz}, 1 \mathrm{H}), 7.18-7.11(\mathrm{~m}, 2 \mathrm{H}), 7.08-6.91$ (br, 1H), 4.19-3.95 (br, 1H), 3.93-3.77 (br, 1H), 3.75 (s, 2H), 3.33-2.97 (m, 2H), 2.85-2.71 (br, 1H), 2.03-1.92 (m, 1H), 1.91-1.79 (m, 1H), 1.69-1.55 (m, 1H), 1.55-1.40 (m, 1H). MS (ESI) $(\mathrm{M}+\mathrm{H})^{+}=411.4$; HPLC analysis: $95.6 \%$ purity.

Compound 17: (S)-5-chloro-2-(3-((3,5-dichlorobenzyl)oxy)piperidin-1-yl)-1H-imidazo[4,5b]pyridine was synthesized using (S)-3-((3,5-dichlorobenzyl)oxy)piperidine. ${ }^{1} \mathrm{H}$ NMR (500 MHz, MeOD) $\delta 7.69(\mathrm{~d}, J=8.3 \mathrm{~Hz}, 1 \mathrm{H}), 7.34(\mathrm{~d}, J=8.3 \mathrm{~Hz}, 1 \mathrm{H}), 7.24-7.21(\mathrm{~m}, 1 \mathrm{H}), 7.17-7.14$ (m, 2H), 4.67 (d, $J=12.7 \mathrm{~Hz}, 1 \mathrm{H}), 4.55$ (d, $J=12.7 \mathrm{~Hz}, 1 \mathrm{H}), 4.56$ (s, 1H), 4.54 (s, 1H), 3.99 (dd, $J=14.0,3.7 \mathrm{~Hz}, 1 \mathrm{H}), 3.95-3.86(\mathrm{~m}, 2 \mathrm{H}), 3.78(\mathrm{~d}, J=13.8 \mathrm{~Hz}, 1 \mathrm{H}), 3.61(\mathrm{ddd}, J=13.6,10.5$, 
$3.0 \mathrm{~Hz}, \quad 1 \mathrm{H}), \quad 2.15-2.04(\mathrm{~m}, 2 \mathrm{H}), 2.01-1.93(\mathrm{~m}, 1 \mathrm{H}), 1.82-1.73(\mathrm{~m}, 1 \mathrm{H}) . \quad \mathrm{MS}$ (ESI) $(\mathrm{M}+\mathrm{H})^{+}=412.8$. HPLC analysis: $97.5 \%$ purity.

Compound 18 : 3,5-dichloro-N-((1-(5-chloro-1H-imidazo[4,5-b]pyridin-2-yl)piperidin-3$y$ l)methyl)aniline was synthesized using 3,5-dichloro-N-(piperidin-3-ylmethyl)aniline. ${ }^{1} \mathrm{H}$ NMR (500 MHz, MeOD) $\delta 7.70(\mathrm{~d}, J=7.8 \mathrm{~Hz}, 1 \mathrm{H}), 7.39-7.27(\mathrm{~m}, 1 \mathrm{H}), 6.63-6.49$ (m, 3H), 4.05 (d, $J$ $=9.2 \mathrm{~Hz}, 1 \mathrm{H}), 3.96-3.89(\mathrm{~m}, 1 \mathrm{H}), 3.49-3.41(\mathrm{~m}, 1 \mathrm{H}), 3.12(\mathrm{dd}, J=29.3,15.1 \mathrm{~Hz}, 2 \mathrm{H}), 2.18-$ $1.91(\mathrm{~m}, 3 \mathrm{H}), 1.85-1.69(\mathrm{~m}, 1 \mathrm{H}), 1.58-1.42(\mathrm{~m}, 1 \mathrm{H}), 1.37-1.21(\mathrm{~m}, 1 \mathrm{H}) . \mathrm{MS}(\mathrm{ESI})(\mathrm{M}+\mathrm{H})^{+}=$ 412.0; HPLC analysis: 95.0\% purity.

Compound 19: (S)-1-(5-chloro-1H-imidazo[4,5-b]pyridin-2-yl)-N-(3,5-dichlorophenyl) piperidine-3-carboxamide was synthesized using (R)-N-(3,5-dichlorophenyl)piperidine-3carboxamide. ${ }^{1} \mathrm{H}$ NMR (500 MHz, DMSO) $\delta 10.4$ (s, 1H), 7.74-7.66 (m, 1H), 7.49 (d, $J=8.0$ $\mathrm{Hz}, 1 \mathrm{H}), 7.30$ (t, $J=1.7 \mathrm{~Hz}, 1 \mathrm{H}), 7.03-6.88(\mathrm{~m}, 1 \mathrm{H}), 4.27$ (d, $J=12.3 \mathrm{~Hz}, 1 \mathrm{H}), 4.12$ (d, $J=12.9$ $\mathrm{Hz}, 1 \mathrm{H}), 3.28-3.17(\mathrm{~m}, 1 \mathrm{H}), 3.11(\mathrm{t}, J=11.4 \mathrm{~Hz}, 1 \mathrm{H}), 2.63(\mathrm{tt}, J=10.9,3.5 \mathrm{~Hz}, 1 \mathrm{H}), 2.05(\mathrm{~d}, J$ $=10.7 \mathrm{~Hz}, 1 \mathrm{H}), 1.82(\mathrm{~d}, J=13.2 \mathrm{~Hz}, 1 \mathrm{H}), 1.74(\mathrm{qd}, J=12.4,3.5 \mathrm{~Hz}, 1 \mathrm{H}), 1.55(\mathrm{qd}, J=12.5,4.2$ $\mathrm{Hz}, 1 \mathrm{H})$. MS (ESI) $(\mathrm{M}+\mathrm{H})^{+}=426.0$; HPLC analysis: $>99.9 \%$ purity.

Compound 20: (S)-3,5-dichloro-N-(1-(5-chloro-1H-imidazo[4,5-b]pyridin-2-yl)piperidin-3$y l$ )benzamide was synthesized using (R)-3,5-dichloro-N-(piperidin-3-yl)benzamide. ${ }^{1} \mathrm{H}$ NMR (500 MHz, DMSO) $\delta 8.65(\mathrm{~d}, J=7.8 \mathrm{~Hz}, 1 \mathrm{H}), 7.85(\mathrm{~d}, J=1.8 \mathrm{~Hz}, 2 \mathrm{H}), 7.81(\mathrm{t}, J=1.8 \mathrm{~Hz}, 1 \mathrm{H})$, $7.46(\mathrm{~d}, J=8.0 \mathrm{~Hz}, 1 \mathrm{H}), 6.94(\mathrm{~d}, J=7.8 \mathrm{~Hz}, 1 \mathrm{H}), 4.14(\mathrm{dd}, J=12.6,3.7 \mathrm{~Hz}, 1 \mathrm{H}), 4.06-3.91(\mathrm{~m}$, 2H), 3.21-3.06 (m, 2H), 2.02-1.92 (m, 1H), 1.92-1.82 (m, 1H), 1.70-1.55 (m, 2H). MS (ESI) $(\mathrm{M}+\mathrm{H})^{+}=426.0$; HPLC analysis: $>99.9 \%$ purity.

Compound 21: 1-(5-chloro-1H-imidazo[4,5-b]pyridin-2-yl)-N-(3,5-dichlorobenzyl)piperidin -4amine was synthesized using tert-butyl piperidin-4-ylcarbamate. ${ }^{1} \mathrm{H}$ NMR $\left(500 \mathrm{MHz}, \mathrm{CDCl}_{3}\right) \delta$ 7.80-7.43 (br, 1H), 7.35-7.21 (m, 3H), 7.13-6.76 (br, 1H), 4.37-3.97 (m, 2H), 3.81 (s, 2H), 3.29-3.06 (br, 2H), $2.78(\mathrm{~s}, 1 \mathrm{H}), 2.00-1.92$ (br, 2H), 1.53-1.40 (br, 2H). MS (ESI) $(\mathrm{M}+\mathrm{H})^{+}=$ 411.7; HPLC analysis: $95.5 \%$ purity.

Compound 22: 1-(5-chloro-1H-imidazo[4,5-b]pyridin-2-yl)-N-(3,5-dichlorobenzyl)azetidin-3amine was synthesized using tert-butyl azetidin-3-ylcarbamate. ${ }^{1} \mathrm{H}$ NMR $\left(500 \mathrm{MHz}, \mathrm{CDCl}_{3}\right) \delta$ 7.80-7.43 (br, 1H), 7.35-7.21 (m, 3H), 7.13-6.76 (br, 1H), 4.37-3.97 (m, 2H), 3.81 (s, 2H), 
3.29-3.06 (br, 2H), $2.78(\mathrm{~s}, 1 \mathrm{H}), 2.00-1.92(\mathrm{br}, 2 \mathrm{H}), 1.53-1.40(\mathrm{br}, 2 \mathrm{H})$. MS (ESI) $(\mathrm{M}+\mathrm{H})^{+}=$ 383.6; HPLC analysis: > 99.9\% purity.

Compound 23: (R)-1-(5-chloro-3H-imidazo[4,5-b]pyridin-2-yl)-N-(3,5-dichlorobenzyl) pyrrolidin-3-amine was synthesized using tert-butyl (R)-pyrrolidin-3-ylcarbamate. ${ }^{1} \mathrm{H}$ NMR (500 MHz, MeOD) $\delta 7.43-7.37(\mathrm{~m}, 4 \mathrm{H}), 6.96(\mathrm{~d}, J=8.0 \mathrm{~Hz}, 1 \mathrm{H}), 3.86(\mathrm{~s}, 2 \mathrm{H}), 3.74-3.70(\mathrm{~m}, 2 \mathrm{H})$, 3.54-3.48 (m, 2H), 3.48-3.43 (m, 1H), $2.29(\mathrm{~s}, 1 \mathrm{H}), 2.00-2.17(\mathrm{~m}, 1 \mathrm{H})$. MS (ESI) $(\mathrm{M}+\mathrm{H})^{+}=$ 397.5. HPLC analysis: $95.2 \%$ purity.

Compound 24: (S)-1-(5-chloro-3H-imidazo[4,5-b]pyridin-2-yl)-N-(3,5-dichlorobenzyl) pyrrolidin-3-amine was synthesized using tert-butyl (S)-pyrrolidin-3-ylcarbamate. ${ }^{1} \mathrm{H}$ NMR (500 MHz, MeOD) $\delta 7.43-7.37(\mathrm{~m}, 4 \mathrm{H}), 6.95(\mathrm{~d}, J=8.0 \mathrm{~Hz}, 1 \mathrm{H}), 3.85(\mathrm{~s}, 2 \mathrm{H}), 3.70-3.64(\mathrm{~m}, 2 \mathrm{H})$, $3.52-3.48(\mathrm{~m}, 2 \mathrm{H}), 3.48-3.41(\mathrm{~m}, 1 \mathrm{H}), 2.30(\mathrm{~s}, 1 \mathrm{H}), 2.00-1.97(\mathrm{~m}, 1 \mathrm{H}) . \mathrm{MS}(\mathrm{ESI})(\mathrm{M}+\mathrm{H})^{+}=$ 397.5. HPLC analysis: $97.3 \%$ purity.

Compound 25: 1-(5-chloro-1H-imidazo[4,5-b]pyridin-2-yl)-N-(3,5-dichlorobenzyl)azepan-3amine was synthesized using tert-butyl azepan-3-ylcarbamate. ${ }^{1} \mathrm{H}$ NMR $(500 \mathrm{MHz}, \mathrm{MeOD}) \delta$ 7.43-7.40 (m, 2H), 7.439(s, 1H), 7.34-7.31 (m, 1H), 6.95-6.91(d, J= 8.0, 1H) 4.0-3.9 (m, 1H), 3.88 (s, 2H) 3.76-3.66 (m, 1H), 3.60-3.49 (m, 2H), 3.00-2.89 (br, 1H), 1.99-1.73 (m, 4H), 1.48$1.41(\mathrm{~m}, 2 \mathrm{H}) . \mathrm{MS}(\mathrm{ESI})(\mathrm{M}+\mathrm{H})^{+}=425.9$. HPLC analysis: $96.0 \%$ purity.

Compound 31: N1-(5-chloro-1H-imidazo[4,5-b]pyridin-2-yl)-N2-(3,5-dichlorobenzyl)-N1methylethane-1,2-diamine was synthesized using tert-butyl (2-(methylamino)ethyl)carbamate. ${ }^{1} \mathrm{H}$ NMR (500 MHz, MeOD) $\delta 7.45(\mathrm{~d}, J=7.7 \mathrm{~Hz}, 1 \mathrm{H}), 7.33-7.28(\mathrm{~m}, 3 \mathrm{H}), 6.98(\mathrm{~d}, J=8.0 \mathrm{~Hz}$, $1 \mathrm{H}), 3.93(\mathrm{~s}, 2 \mathrm{H}), 3.71-3.67(\mathrm{~m}, 2 \mathrm{H}), 3.19(\mathrm{~s}, 3 \mathrm{H}), 3.06-3.00(\mathrm{~m}, 2 \mathrm{H}) . \mathrm{MS}(\mathrm{ESI})(\mathrm{M}+\mathrm{H})^{+}=$ 385.6. HPLC analysis: $98.3 \%$ purity.

\section{Procedures for the synthesis of compound 27 (Scheme 3).}

(a) DMF $(1.0 \mathrm{~mL})$ solution of aldehyde $(1.0 \mathrm{mmol})$ was added dropwise to a mixture of 6chloropyridine-2, 3-diamine $(1.0 \mathrm{mmol})$, and sodium bisulfite $(1.0 \mathrm{mmol})$ in DMF $(1.0 \mathrm{~mL})$ was added over a $10 \mathrm{~min}$ period at $100{ }^{\circ} \mathrm{C}$. After $2 \mathrm{~h}$, the reaction mixture was concentrated, the residue was purified by flash column chromatography (DCM/MeOH) to give tert-butyl (3-(5chloro-3H-imidazo [4, 5-b] pyridin-2-yl) propyl) carbamate 38. 
(b,c) Following the general procedures in Scheme 2 to remove Boc with TFA, followed with the reductive amination reaction with 3,5-dichlorobenzaldehyde yields the target compound 27: 3(5-chloro-3H-imidazo [4,5-b] pyridin-2-yl)-N-(3,5-dichlorobenzyl)propan-1-amine. ${ }^{1} \mathrm{H}$ NMR (500 MHz, MeOD) $\delta 7.90(\mathrm{~d}, J=8.3 \mathrm{~Hz}, 1 \mathrm{H}), 7.21-7.26(\mathrm{~m}, 3 \mathrm{H}), 7.28(\mathrm{~d}, J=8.2 \mathrm{~Hz}, 1 \mathrm{H}), 3.90$ $(\mathrm{s}, 2 \mathrm{H}), 3.04(\mathrm{t}, J=7.2 \mathrm{~Hz}, 2 \mathrm{H}), 2.83(\mathrm{t}, J=6.6 \mathrm{~Hz}, 2 \mathrm{H}), 2.16-2.10(\mathrm{~m}, 2 \mathrm{H}) . \mathrm{MS}(\mathrm{ESI})(\mathrm{M}+\mathrm{H})^{+}$ = 370.7. HPLC analysis: $97.8 \%$ purity.

\section{Procedures for the synthesis of compound 28 (Scheme 4).}

(a) Compound 5-chloro-1H-imidazo[4,5-b]pyridine-2(3H)-thione 39 (1 eq), 2-(2-bromoethyl) isoindoline-1,3-dione (1 eq) were dissolved in $\mathrm{CH}_{3} \mathrm{CN}, \mathrm{K}_{2} \mathrm{CO}_{3}$ (4 eq) was added and the resulting mixture was stirred at room temperature overnight. The mixture was extracted with DCM, washed with brine, concentrated under vacuum and purified via flash column chromatography $(10 \% \mathrm{MeOH}$ in DCM ) to yield the intermediate 40: 2-(2-((5-chloro-1H-imidazo[4,5-b]pyridin2-yl)thio)ethyl)isoindoline-1,3-dione. MS (ESI) $[\mathrm{M}+\mathrm{H}]^{+}=361.3$

(b) 2-(2-((5-chloro-1H-imidazo[4,5-b]pyridin-2-yl)thio)ethyl)isoindoline-1,3-dione was dissolved in $\mathrm{MeOH}$, hydrazine (2 eq) was added, the mixture was then microwave irradiated at $70 \square \mathrm{C}$ for $20 \mathrm{~min}$. The solvent was evaporated off and residue was purified via flash column chromatography directly eluting with $20 \% \mathrm{MeOH}$ in DCM to yield intermediate 41: 2-((5chloro-1H-imidazo[4,5-b]pyridin-2-yl)thio)ethanamine.MS (ESI) $[\mathrm{M}+\mathrm{H}]^{+}=229.7$

(c) 2-((5-chloro-1H-imidazo[4,5-b]pyridin-2-yl)thio)ethanamine was dissolved in $\mathrm{MeOH}, 3,5-$ dichlorobenzaldehyde (1.1 equiv) was added, then $\mathrm{AcOH}$ was added (2 eq). After the mixture was stirred for 30 min, $\mathrm{NaBH}_{3} \mathrm{CN}$ (2 equiv) was added. The mixture was stirred overnight and the solvent was removed under vacuum. The residue was dissolved in DCM and washed with sat. sodium bicarbonate and brine. The organic layer was dried over $\mathrm{Na}_{2} \mathrm{SO}_{4}$ and concentrated under vacuum. The residue was purified by flash column chromatography (DCM/MeOH), yielding compound 28: 2-((5-chloro-1H-imidazo[4,5-b]pyridin-2-yl)thio)-N-(3,5-dichlorobenzyl) ethanamine as white solid. ${ }^{1} \mathrm{H}$ NMR $\left(500 \mathrm{MHz}, \mathrm{CDCl}_{3}\right) \delta 7.47(\mathrm{~d}, J=8.0 \mathrm{~Hz}, 1 \mathrm{H}), 7.26(\mathrm{~s}, 1 \mathrm{H})$, $7.15(\mathrm{~s}, 2 \mathrm{H}), 7.00(\mathrm{~d}, J=8.0 \mathrm{~Hz}, 1 \mathrm{H}), 4.82(\mathrm{~s}, 2 \mathrm{H}), 3.75(\mathrm{t}, J=6.9 \mathrm{~Hz}, 1 \mathrm{H}), 2.81(\mathrm{t}, J=6.9 \mathrm{~Hz}$, 1H). MS (ESI) $[\mathrm{M}+\mathrm{H}]^{+}=388.8$. HPLC analysis: $97.8 \%$ purity.

\section{General procedures for the synthesis of compounds 29 and 30 (Scheme 5).}


(a): To the solution of tert-butyl 3,5-dichlorobenzyl-2-isothiocyanatoethylcarbamate 42 (1 eq) in anhydrous acetonitrile was added the aromatic diamine 33 (1 eq). The mixture was refluxed for 20h. After the solvent was removed, the residue was recrystallized in EtOAc/hexane twice to give the thiourea.

(b) To the solution of the thiourea (1 eq) in anhydrous acetonitrile (warm to dissolve), DIC (2 eq) was added. The solution was refluxed for $10 \mathrm{~h}$. After cooling down, the white precipitate was collected by filtration to give the carbamate.

(c) To the solution of carbamate (1 eq) obtained above in dioxane, excess $4 \mathrm{~N} \mathrm{HCl}$ in dioxane was added. The precipitate was formed in $5 \mathrm{~min}$. The mixture was continued to stir overnight. The solid was collected and washed with dioxane to obtain the white solid as target compound.

Compound 29: N1-(6-chloro-1H-benzo[d]imidazol-2-yl)-N2-(3,5-dichlorobenzyl)ethane-1,2diamine in $\mathrm{HCl}$ form was synthesized using 4-chlorobenzene-1,2-diamine. ${ }^{1} \mathrm{H} \mathrm{NMR}(500 \mathrm{MHz}$, MeOD) $\delta 7.46-7.40(\mathrm{~m}, 3 \mathrm{H}), 7.18(\mathrm{~s}, 1 \mathrm{H}), 7.13(\mathrm{~d}, J=8.3 \mathrm{~Hz}, 1 \mathrm{H}), 6.98(\mathrm{~d}, J=8.3 \mathrm{~Hz}, 1 \mathrm{H})$, $4.01(\mathrm{~s}, 2 \mathrm{H}), 3.62-3.56(\mathrm{~m}, 2 \mathrm{H}), 3.10-3.04(\mathrm{~m}, 2 \mathrm{H})$. MS (ESI) $(\mathrm{M}+\mathrm{H})^{+}=370.6$. HPLC analysis: $98.5 \%$ purity.

Compound 30: N1-(5-chloro-3H-imidazo[4,5-b]pyridin-2-yl)-N2-(3,5-dichlorobenzyl) ethane1,2-diamine was synthesized using 6-chloropyridine-2,3-diamine. ${ }^{1} \mathrm{H}$ NMR (500 MHz, MeOD) $\delta$ 7.43-7.39 (m, 3H), 7.30 (s, 1H), 6.97 (d, $J=8.1 \mathrm{~Hz}, 1 \mathrm{H}), 3.97(\mathrm{~s}, 2 \mathrm{H}), 3.65-3.60$ (m, 2H), 3.042.98(m, 2H). MS (ESI) $(\mathrm{M}+\mathrm{H})^{+}=371.7$. HPLC analysis: $98.6 \%$ purity.

\section{Thermal shift assay}

Thermal shift assays were performed in white 96-well plates (Bio-Rad) using the fluorescent dye SYPRO Orange (Invitrogen). $100 \mu \mathrm{l}$ of $9.6 \mathrm{mg} / \mathrm{ml}$ protein was diluted in $1.2 \mathrm{ml}$ assay buffer (100 mM HEPES, pH 7.5, $100 \mathrm{mM} \mathrm{NaCl}, 10 \mathrm{mM}$ ATP-Mg) containing $2 \mu \mathrm{l}$ of SYPRO Orange DMSO solution sold as " $5000 \mathrm{x}$ ". $1 \mu \mathrm{L}$ of $20 \mathrm{mM}$ stock solution of test compounds in DMSO (100 $\mu \mathrm{M}$ final concentration) was pipetted into $9 \mu \mathrm{l}$ of assay buffer and mixed with $10 \mu \mathrm{l}$ of the above protein solution in each well. The 96-well plate was sealed with a transparent film (Bio$\mathrm{Rad}$ ) and centrifuged for $3 \mathrm{~min}$ at $800 \mathrm{rpm}$ to ensure that samples were at the bottom of their wells and any bubble was removed. Temperature-dependent fluorescence increase reporting protein denaturation was measured in triplicate using a DNA Engine Opticon 2 instrument (Bio- 
Rad) from 25 to $90{ }^{\circ} \mathrm{C}$ in steps of $0.2{ }^{\circ} \mathrm{C}$ (excitation $470-505 \mathrm{~nm}$; emission $540-700 \mathrm{~nm}$ ). A $\mathrm{T}_{\mathrm{m}}$ for each well was determined with the First Derivative method, which used Opticon Monitor software (Bio-Rad) to smooth the raw fluorescence data (converting each data point into a moving average of itself and adjacent points) and then finding the temperature at which the upward slope of the fluorescence versus temperature curve was the steepest - that is, the temperature at which the first derivative of this curve was maximal.

\section{T. brucei growth inhibition assay}

The assay is performed in the same procedure as described in a previous publications $[8,14]: T$. brucei (bloodstream form strain 427 from Dr. K. Stuart, Seattle Biomedical Research Institute, Seattle, WA) was cultured in HMI-9 medium containing 10\% fetal bovine serum, penicillin, and streptomycin at $37^{\circ} \mathrm{C}$ with $5 \% \mathrm{CO}_{2}$. Drug sensitivity of the T. brucei strain was determined in 96 well microtiter plates in triplicate with an initial inoculum of $1 \times 10^{4}$ trypomastigotes per well. Compound stock solutions were prepared in DMSO at $20 \mathrm{mM}$ and added in serial dilutions for a final volume of $200 \mu \mathrm{l} /$ well. Parasite growth was quantified at $48 \mathrm{~h}$ by the addition of Alamar Blue (ThermoFisher Scientific, Waltham, MA). Pentamidine isethionate (Aventis, Dagenham, UK) was included in each assay as a positive control.

\section{Enzyme inhibition assay}

Compounds were assayed against $T$. brucei methionyl-tRNA synthetase (TbMetRS) in triplicate using an ATP-depletion chemiluminescence assay in a 96-well format as previously described. ${ }^{12}$ Briefly, compounds were pre-incubated for 15 minutes at room temperature with $200 \mu \mathrm{g} / \mathrm{mL}$ bulk E. coli tRNA (Sigma-Aldrich or the equivalent activity of Roche), $50 \mathrm{nM}$ TbMetRS, 0.1 $\mathrm{U} / \mathrm{mL}$ pyrophosphatase, $0.2 \mathrm{mM}$ spermine, $0.1 \mathrm{mg} / \mathrm{mL}$ bovine serum albumin, $2.5 \mathrm{mM}$ dithiothreitol, $25 \mathrm{mM}$ HEPES-KOH pH 7.9, $10 \mathrm{mM} \mathrm{MgCl}_{2}, 50 \mathrm{mM} \mathrm{KCl}$, and 2\% DMSO. Then $100 \mathrm{nM}$ ATP and $32 \mu \mathrm{M}$ L-methionine was added to start the reaction. After a 120 minute incubation, an equal volume $(50 \mu \mathrm{L})$ of Kinase-Glo® (Promega) was added and the relative light units were quantified.

Percent inhibition $=100 \times($ test compound - AVG low control $) /($ AVG high control - AVG low control). Where low control is everything except compounds and high control is everything except compounds and L-methionine. $\mathrm{IC}_{50}$ values were calculated by non-linear regression, sigmoidal-dose response, in Prism 3.0. 


\section{Mammalian cell growth inhibition assays.}

The assay is performed in the same procedure as described in previous publication [9] : The human lymphocytic cell line CRL-1855 (American Type Culture Collection) were grown in RPMI medium (Lonza, Walkersville, MD) with $10 \%$ fetal bovine serum at $37{ }^{\circ} \mathrm{C}$ with $5 \% \mathrm{CO}_{2}$. The human hepatocellular cell line HepG2 (American Type Culture Collection) were grown in DMEM/F-12 medium (Lonza, Walkersville, MD) with $10 \%$ fetal calf serum. Cells $(5 \times 103$ /well) were added to 96-well plates and incubated with serial dilutions of compounds in quadruplicate for $48 \mathrm{~h}$. At that time, cell viability was quantified by addition of Alamar Blue, and plates were incubated for an additional $4 \mathrm{~h}$ at $5 \% \mathrm{CO}_{2}, 37{ }^{\circ} \mathrm{C}$. Absorbance readings (OD570-600) were used to calculate viability referenced against cells grown with no inhibitors.

\section{PK studies in mice}

The assay is performed in the same procedure as described in previous publications [14,16-18] : Compounds were administered by oral gavage at a concentration of $50 \mathrm{mg} / \mathrm{kg}$ in a volume of 0.2 $\mathrm{mL}$ of dosing solution (7\% tween $80,3 \%$ ethanol, 5\% DMSO, $0.9 \%$ saline) to mice by oral gavage. Tail blood was then collected at time points of 30, 60, 120, 240, 260 and 480 minutes into a heparinized capillary tube and $30 \mu \mathrm{l}$ was then spotted onto a Whatman FTA DMPK-C Card (GE, Fairfield, CT.) Blood samples were analyzed by extracting the dried blood spots [19] in acetonitrile for measurements of compound concentrations by liquid chromatography/tandem mass spectrometry.

\section{Distribution of compounds between mouse plasma and brain}

This experiment is adapted from a previous reported procedure [18] : Mice ( $n=3)$ were injected IP with $5 \mathrm{mg} / \mathrm{kg}$ of the test compound dissolved in $400 \mu \mathrm{l}$ of dosing solution (7\% tween 80, 3\% $\mathrm{EtOH}, 5 \% \mathrm{DMSO}, 0.9 \%$ saline) and sacrificed at $60 \mathrm{~min}$ for collection of plasma and brains. The brains were removed, weighed, and frozen to be later homogenized in acetonitrile using a Dounce homogenizer. Blood was briefly centrifuged to separate out the plasma for determining plasma concentrations of the compound. Concentrations of compound in the plasma and brain tissue was determined by liquid chromatography/tandem mass spectrometry analysis relative to a standard compound amount. The concentration of compound in the brain was obtained by dividing the moles of compound in the brain by the brain volume (obtained from the brain weight assuming $1 \mathrm{~g}$ is $1 \mathrm{~mL}$ ) and correcting for the brain vasculature volume of $3 \%$ by weight. 
All animal study protocols were approved by the Institutional Animal Care and Use Committee of the University of Washington (IACUC no. 4248-01).

\section{Acknowledgements and Funding Source}

Research reported in this publication was supported by the National Institute of Allergy and Infectious Diseases of the National Institutes of Health under award numbers R01AI084004 and R01AI097177. The content is solely the responsibility of the authors and does not necessarily represent the official views of the National Institutes of Health.

Crystallography performed in support of the work benefited from remote access to resources at the Stanford Synchrotron Radiation Light source supported by the U.S. Department of Energy Office of Basic Energy Sciences under Contract No. DE-AC02-76SF00515 and by the National Institutes of Health (P41GM103393).

\section{Abbreviations Used}

AP, auxiliary pocket; CNS, central nervous system; EMP, enlarged methionine pocket; HAT, Human African trypanosomiasis; MetRS, methionyl-tRNA synthetase; SAR, structure-activity relationship.

\section{REFERENCES}

[1] P.J. Hotez, D.H. Molyneux, A. Fenwick, J. Kumaresan, S.E. Sachs, J.D. Sachs, L. Savioli, Control of neglected tropical diseases. N. Engl. J. Med. 357 (2007) 1018-1027.

[2] R. Brun, J. Blum, F. Chappuis, C. Burri, Human African trypanosomiasis. Lancet. 375 (2010) 148-159. 
[3] Mapping the risk of human African trypanosomiasis.

http://www.who.int/trypanosomiasis_african/country/risk_AFRO/en/, 2016 (accessed 07.05.16).

[4] Trypanosomiasis, human African (sleeping sickness).

http://www.who.int/mediacentre/factsheets/fs259/en/, 2016 (accessed 07.05.16).

[5] J. Rodgers, Human African trypanosomiasis, chemotherapy and CNS disease. J

Neuroimmunol. 211 (2009) 16-22.

[6] P. Mäser, S. Wittlin, M. Rottmann, T. Wenzler, M. Kaiser, R. Brun, Antiparasitic agents: new drugs on the horizon. Curr. Opin. Pharmacol. 12 (2012) 562-566.

[7] K. Sheppard, J. Yuan, M.J. Hohn, B. Jester, K.M. Devine, D. Söll. From one amino acid to another: tRNA-dependent amino acid biosynthesis. Nucleic Acids Res. 36 (2008) 1813-1825.

[8] S. Shibata, J.R. Gillespie, A.M. Kelley, A.J. Napuli, Z. Zhang, K.V. Kovzun, R.M. Pefley, J. Lam, F.H. Zucker, W.C. Van Voorhis, E.A. Merritt, W.G. Hol, C.L.M.J. Verlinde, E. Fan, F.S. Buckner, Selective inhibitors of methionyl-tRNA synthetase have potent activity against Trypanosoma brucei infection in mice. Antimicrob. Agents Chemother. 55 (2011) 1982-1989.

[9] S. Shibata, J.R. Gillespie, R.M. Ranade, C.Y. Koh, J.E. Kim, J.U. Laydbak, F.H. Zucker, W.G. Hol, C.L. Verlinde, F.S. Buckner, E. Fan, Urea-Based inhibitors of Trypanosoma brucei Methionyl-tRNA synthetase: selectivity and in vivo characterization. J. Med. Chem. 55 (2012) $6342-6351$.

[10] R.L. Jarvest, J.M. Berge, V. Berry, H.F. Boyd, M.J. Brown, J.S. Elder, A.K. Forrest, A.P. Fosberry, D.R. Gentry, M.J. Hibbs, D.D. Jaworski, P.J. O'Hanlon, A.J. Pope, S. Rittenhouse, R.J. Sheppard, C. Slater-Radosti, A. Worby, Nanomolar inhibitors of Staphylococcus aureus methionyl tRNA synthetase with potent antibacterial activity against gram-positive pathogens. J. Med. Chem. 45 (2002) 1959-1962.

[11] R.L. Jarvest, S.A. Armstrong, J.M. Berge, P. Brown, J.S. Elder, M.J. Brown, R.C. Copley, A.K. Forrest, D.W. Hamprecht, P.J. O'Hanlon, D.J. Mitchell, S. Rittenhouse, D.R. Witty, Definition of the heterocyclic pharmacophore of bacterial methionyl tRNA synthetase inhibitors: potent antibacterially active non-quinolone analogues. Bioorg. Med. Chem. Lett. 14 (2004) 3937-3941.

[12] L. Pedro'- Rosa, F.S. Buckner, R.M. Ranade, C. Eberhart, F. Madoux, J.R. Gillespie, C.Y. Koh, S. Brown, J. Lohse, C.L.M.J. Verlinde, E. Fan, T. Bannister, L. Scampavia, W.G.J. Hol, T. Spicer, P. Hodder, Identification of potent inhibitors of the Trypanosoma brucei methionyl- 
tRNA synthetase via high throughput orthogonal screening, J. Biomol. Screening. 20 (2015) $122-130$.

[13] C.Y. Koh, J.E. Kim, S. Shibata, R.M. Ranade, M. Yu, J. Liu, J.R. Gillespie, F.S. Buckner, C.L.M.J. Verlinde, E. Fan, W.G. Hol, Distinct states of Methionyl-tRNA synthetase indicate inhibitor binding by conformational selection, Structure. 20 (2012) 1681-1699.

[14] Z. Zhang, C.Y. Koh, R.M. Ranade, S. Shibata, J.R. Gillespie, M.A. Hulverson, W. Huang, J. Nguyen, N. Pendem, M.H.Gelb, C.L.M.J. Verlinde, W.G.J. Hol, F.S. Buckner, E. Fan, 5Fluoroimidazo[4,5-b]pyridine as a privileged fragment that conveys bioavailability to potent Trypanosomal Methionyl-tRNA synthetase inhibitors, ACS Infect Dis. 2 (2016) 399-404. [15] R.M. Ranade, Z. Zhang, J.R. Gillespie, S. Shibata, C.L.M.J. Verlinde, W.G.J. Hol, E. Fan, F.S. Buckner, Inhibitors of methionyl-tRNA synthetase have potent activity against Giardia intestinalis trophozoites. Antimicrob. Agents Chemother. 59 (2015) 7128-7131.

[16] J.M. Kraus, C.L.M.J.. Verlinde, M. Karimi, G.I. Lepesheva, M.H. Gelb, F.S. Buckner, Rational modification of a candidate cancer drug for use against Chagas disease. J. Med. Chem. 52 (2009) 1639-1647.

[17] P.K. Suryadevara, S. Olepu, J.W. Lockman, J. Ohkanda, M. Karimi, C.L.M.J. Verlinde, J.M. Kraus, J. Schoepe, W.C. Van Voorhis, A.D. Hamilton, F.S. Buckner, M.H. Gelb , Structurally simple inhibitors of Lanosterol $14 \alpha$-demethylase are efficacious in a rodent model of acute Chagas disease. J. Med. Chem. 52 (2009) 3703-3715.

[18] H.B. Tatipaka, J.R. Gillespie, A.K. Chatterjee, N.R. Norcross, N. R, M.A. Hulverson, R.M. Ranade, P. Nagendar, S.A. Creason, J. McQueen, N.A. Duster, A. Nagle, F. Supek, V. Molteni, T. Wenzler, R. Brun, R. Glynne, F.S. Buckner, M.H. Gelb, Substituted 2-

Phenylimidazopyridines: A new class of drug leads for human African Trypanosomiasis. J. Med. Chem. 57 (2014) 828-835.

[19] M. Rowland, G.T. Emmons, Use of dried blood spots in drug development: pharmacokinetic considerations. AAPS J. 12 (2010) 290-293. 